\title{
Factors Influencing Asia-Pacific Countries' Success Level in Curbing COVID-19: A Review Using a Social-Ecological System (SES) Framework
}

\author{
Gabriel Hoh Teck Ling ${ }^{1, *} \mathbb{D}$, Nur Amiera binti Md Suhud ${ }^{1}$, Pau Chung Leng ${ }^{1} \mathbb{D}$, Lee Bak Yeo ${ }^{2,3} \mathbb{D}^{\mathbb{D}}$, \\ Chin Tiong Cheng ${ }^{2}$, Mohd Hamdan Haji Ahmad ${ }^{1}$ and Ak Mohd Rafiq Ak Matusin ${ }^{1}$ (I) \\ 1 Faculty of Built Environment and Surveying, Universiti Teknologi Malaysia, Skudai 81310, Malaysia; \\ amiera@graduate.utm.my (N.A.b.M.S.); pcleng2@utm.my (P.C.L.); b-hamdan@utm.my (M.H.H.A.); \\ akmohdrafiq@utm.my (A.M.R.A.M.) \\ 2 Tunku Abdul Rahman University College, Kuala Lumpur 53300, Malaysia; yeolb@tarc.edu.my (L.B.Y.); \\ chengct@tarc.edu.my (C.T.C.) \\ 3 Faculty of Architecture and Ekistics, Universiti Malaysia Kelantan, Bachok 16300, Malaysia \\ * Correspondence: gabriel.ling@utm.my
}

\section{check for} updates

Citation: Ling, G.H.T.; Md Suhud, N.A.b.; Leng, P.C.; Yeo, L.B.; Cheng, C.T.; Ahmad, M.H.H.; Ak Matusin, A.M.R. Factors Influencing Asia-Pacific Countries' Success Level in Curbing COVID-19: A Review Using a Social-Ecological System (SES) Framework. Int. J. Environ. Res. Public Health 2021, 18, 1704. https:// doi.org/10.3390/ijerph18041704

Academic Editors: Michel Kazatchkine and Sana de Courcelles

Received: 7 December 2020

Accepted: 4 February 2021

Published: 10 February 2021

Publisher's Note: MDPI stays neutral with regard to jurisdictional claims in published maps and institutional affiliations.

Copyright: (c) 2021 by the authors Licensee MDPI, Basel, Switzerland. This article is an open access article distributed under the terms and conditions of the Creative Commons Attribution (CC BY) license (https:// creativecommons.org/licenses/by/ $4.0 /)$

\begin{abstract}
Little attention has been paid to the impacts of institutional-human-environment dimensions on the outcome of Coronavirus disease 2019 (COVID-19) abatement. Through the diagnostic social-ecological system (SES) framework, this review paper aimed to investigate what and how the multifaceted social, physical, and governance factors affected the success level of seven selected Asia-Pacific countries (namely, South Korea, Japan, Malaysia, Singapore, Vietnam, Indonesia, and New Zealand) in combatting COVID-19. Drawing on statistical data from the Our World In Data website, we measured the COVID-19 severity or abatement success level of the countries on the basis of cumulative positive cases, average daily cases, and mortality rates for the period of 1 February 2020 to 30 June 2020. A qualitative content analysis using three codes, i.e., present (P), partially present (PP), and absent (A) for each SES attribute, as well as score calculation and rank ordering for government response effectiveness and the abatement success level across the countries, was undertaken. Not only did the standard coding process ensure data comparability but the data were deemed substantially reliable with Cohen's kappa of 0.76. Among 13 attributes of the SES factors, high facility adequacy, comprehensive COVID-19 testing policies, strict lockdown measures, imposition of penalty, and the high trust level towards the government seemed to be significant in determining the COVID-19 severity in a country. The results show that Vietnam (ranked first) and New Zealand (ranked second), with a high presence of attributes/design principles contributing to high-level government stringency and health and containment indices, successfully controlled the virus, while Indonesia (ranked seventh) and Japan (ranked sixth), associated with the low presence of design principles, were deemed least successful. Two lessons can be drawn: (i) having high number of P for SES attributes does not always mean a panacea for the pandemic; however, it would be detrimental to a country if it lacked them severely, and (ii) some attributes (mostly from the governance factor) may carry higher weightage towards explaining the success level. This comparative study providing an overview of critical SES attributes in relation to COVID-19 offers novel policy insights, thus helping policymakers devise more strategic, coordinated measures, particularly for effective country preparedness and response in addressing the current and the future health crisis.
\end{abstract}

Keywords: coronavirus; COVID-19; SES framework; institutional-social-ecological system; design principles; Asia-Pacific

\section{Introduction}

Coronavirus disease 2019 (COVID-19) was unknown to the masses prior to its first case in December 2019 [1,2], although there were speculations that the earliest case 
dated back to November 2019 [3]. It was first regarded as viral pneumonia but was then analyzed to be a viral infection that has the capability to be transmitted through human-to-human interaction [4].

As of June 2020, there were countries that had successfully mitigated the problem, while some were struggling and had failed due to countless reasons. Much emphasis has been focused on the science and pharmaceutical dimensions in effort to produce vaccines to cure the pandemic, although it is believed that social behaviors and other potential non-pharmaceutical approaches, despite being intangible, indirect, and leaning towards prosociality (i.e., collective interest) via a cooperative action, can also contribute to curbing the pandemic [5]. Utilizing this research, we carried out an integration between health and the systemic institutional-social-ecological system (SES) framework, apart from knowing its relevancy when applied outside its commons domain, in order to specifically identify answers to the following research question: How can the diagnostic Institutional Analysis and Development (IAD)-SES framework help answer the level of success or failure of countries in curbing the pandemic? It has come to attention that there is a noticeable gap of research in exploring what and how institutional-social-ecological dimensions of the Institutional Analysis and Development (IAD) or SES framework help in understanding the unprecedented crisis. More precisely, given the numerous exogenous factors, this study identifies which SES attributes (design principles) are significant and effective in explaining and thus curbing the pandemic. The framework, synonymous with commons and resource management or collective action, is rarely applied to a health and disease-related topic such as COVID-19; therefore, relationships between the transmission risk or severity of COVID19 and socio-economic and environmental factors via the SES lens should be explored in order to devise a holistic strategy in mitigating the pandemic.

The Institutional Analysis and Development (IAD) framework and SES are both developed by Elinor Ostrom [6]. The former, mostly adopted by social scientists, is primarily used to evaluate the effects of institutional arrangements, as well as the physical environment and local community in explaining a certain contextual outcome. It was envisioned as a systematic tool for scholars of different disciples to communicate with each other regardless of their broad perspectives to pave a way towards better understanding of a situation [7]. Within the framework, it is important to understand the action situation/interaction that actors are in, plausible choices made by them, and how it will affect the pattern of the outcome. In order to predict choices that will be made, we must know (i) the resources brought into the situation; (ii) the valuation assigned by the actor to the state of the world and to the action; (iii) how the actor acquires, processes, retains, and uses the knowledge and information; and (iv) the ways used by the actor in selecting a particular decision [8].

The IAD framework, however, is criticized as it lacks in terms of diversity and complexity of natural system and processes [7]. Therefore, SES is an improved version building upon the IAD framework by expanding the basic variables into more relevant categories, as shown in Figure 1. The SES framework provides a more detailed variable oriented analysis of the social-ecological system [7]. According to Partelow, SES is "a conceptual framework providing a list of variables that may be interacting and affecting outcomes in social-ecological systems" [9]. Via the identified SES attributes, consistent with the application spirit of IAD, we are able to diagnose and explain the interaction (activities) and the outcome of a situation. The community and governance attributes in the IAD context have been maintained as social and governance systems in an SES, while biophysical/ecological attributes converge into two sections, namely, resource systems and resource units. SES, normally applied in the context of commons governance [10], is proven to be versatile and adaptable due to its generality (see the complex adaptive system [11]). It also enables a comparison of different settings in a study where data are collected with the means to compare [9]. 


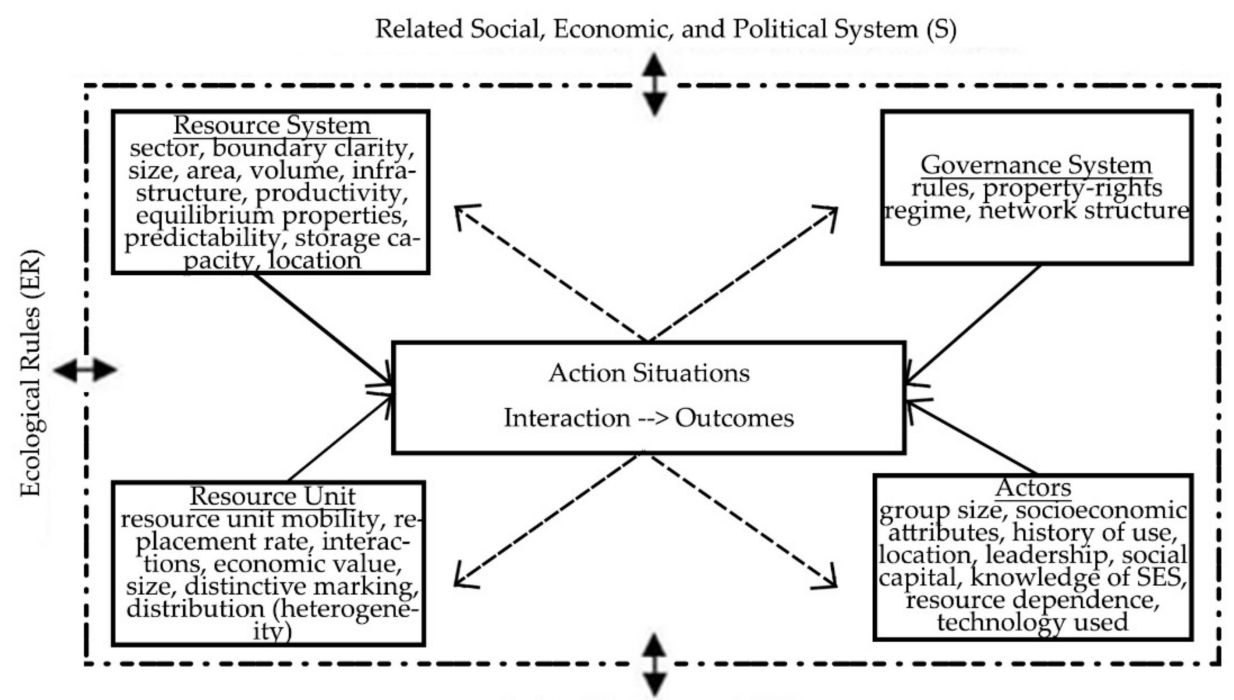

Related Ecosystem (ECO)

$\rightarrow$ Direct causal link

$\rightarrow$ Feedback

Figure 1. Second- and third-tier social-ecological system (SES) attributes. Adapted from Ostrom and Cox [12].

By adopting the SES framework, researchers have an organized variable-oriented and process-oriented line of arguments, involving systematic networks of action situations and hence a more informed decision $[7,13]$. Based on the research conducted by Raboisson and Lhermie [14] and Wilcox et al. [15] situating the SES framework in the human wellbeing and healthcare setting, when adapted into the context of COVID-19, the institutional-socialphysical attributes (e.g., penalty, lockdown, facilities, technology, population density, and past knowledge) and their interaction (e.g., monitoring, communication, swab testing, containment enforcement) would influence the number of cumulative cases, average daily cases, and the mortality rate, and thus translate the success level of a country into low, medium, and high, as diagrammatized in Figure 2.

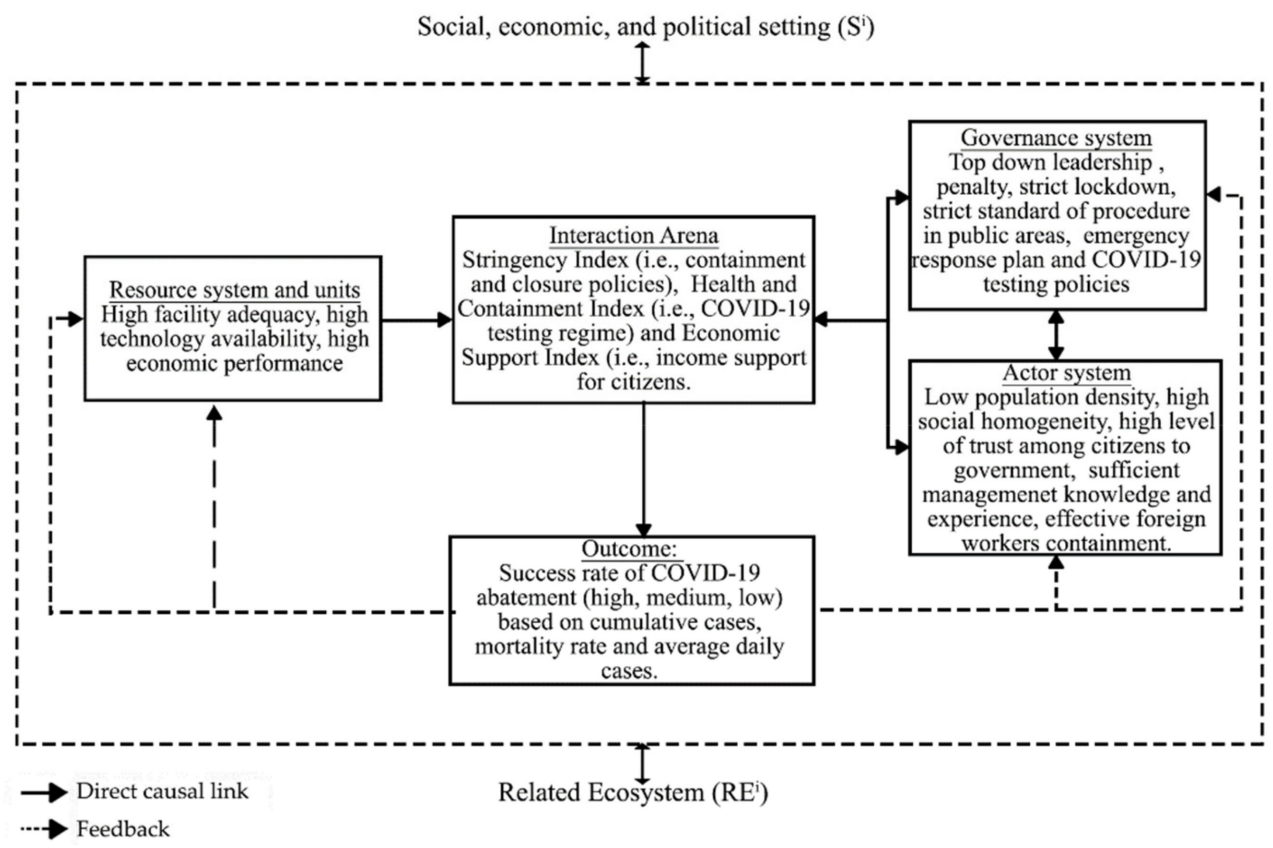

Figure 2. The SES framework in the Coronavirus Disease 2019 (COVID-19) context. Source: Adapted from McGinnis and Ostrom [16]. 
Theoretically, some design principles (DP) or critical success factors that are present in a successful resource management system should also exist in successful pandemic containment and mitigation. The hypothesis was that the higher the amount/frequency of design principles (successful attributes) that are present in countries, the higher the success level of them in curbing the pandemic. Despite all these factors, research focusing on socio-economic and socio-ecological drivers of the COVID-19 transmission remains scarce, when in fact it holds an equally important role as a critical determinant of COVID-19 transmission risks. Although few studies link both socio-ecological and climate factors with transmission levels of COVID-19, one study proved that the latter (climatic factor) does not have a significant effect, and hence its absence in this paper [17]. Therefore, this study attempts to contribute theoretically and methodologically by expanding the application of the SES framework and its institutional-social-ecological design principles in the COVID-19 context. Studying these factors should also be of practical significance because the findings can serve as a reference that helps provide insightful directions about COVID-19 abatement. The following sections of the paper further elaborate the topic in terms of (i) study areas; (ii) methods of data collection and analysis; (iii) results, findings, and discussions; and (iv) lastly a conclusion.

\section{Methodology}

\subsection{Study Areas}

Via the above literature review of SES design principles in terms of primary attributes and their sub-attributes in relation to the COVID-19 context, we carried out a comparative study for the selected countries located in the Asia-Pacific region. This study enlisted Japan, South Korea, Malaysia, Singapore, Vietnam, Indonesia, and New Zealand as study areas and classified them into 3 categories, namely, countries that (i) had successfully flattened the curve (i.e., high success level of abatement), (ii) attempted to flatten the curve (medium success level of abatement), and (iii) failed to flatten the curve. Such categorization was based on their cumulative cases, average daily cases, and mortality rates. Table 1 illustrates overall data of the 3 criteria for each country for the period between 1 February and 30 June 2020. However, since the dates of the data are varied as displayed in the Our World In Data website (due to the fact that each country's first confirmed and mortality cases were different), for better data consistency and accuracy, we processed (standardized) the data prior to using them for the analysis. For example, since the specific timeframe focused here was from 1 February to 30 June 2020, cases displayed in terms of cumulative cases, daily confirmed cases, and mortality rate prior to 1 February 2020 were discounted or excluded from this study. This was important in order to reduce data distortion that would cause imprecision of the result later. From the dataset, Vietnam fared the best, with average daily cases of 2.34 and a mortality rate of $0 \%$, as illustrated in Table 1 . Figure 3 shows that the linear cumulative cases of Vietnam were also the lowest, i.e., 353. The government's swift and strict measures had proven to be successful as the country was one of the earliest to eliminate the virus [18]. Meanwhile, Indonesia recorded the linear cumulative cases of 56,385 with average daily cases of 466, and this figure was the highest among the 7 countries. However, its mortality rate came second after Japan. See Figures 4 and 5 for graphs showing daily confirmed cases and mortality rates across the 7 countries during the period. The next paragraph provides a brief background for each country as to how and when COVID-19 cases started to emerge.

Cases of COVID-19 had first emerged in these countries from early January to the end of February. In some countries, COVID-19 was brought in by Chinese nationals or individuals returning from China or Iran, such as in Singapore, New Zealand, and Japan [19-21]. Indonesia recorded its first case after a national came in contact with an infected person in Malaysia [22]. Even so, Japan was the first country recording a humanto-human transmission as its first case did not visit the market but was in close contact with a pneumonia patient [20]. In some countries, the first case did not necessarily lead to a booming number of cases. In Malaysia, cases started to skyrocket due to a religious event 
in Sri Petaling in March, attended by almost 16,000 individuals from Malaysia and other countries [23]. The same phenomenon occurred in South Korea when an elderly woman in Daegu was tested positive for the virus. She attended a 10,000-member mass gathering at the Shincheonji Church [24].

Table 1. Data of cumulative cases, average daily cases, and the mortality rate from 1 February to 30 June 2020.

\begin{tabular}{cccc}
\hline Country & Cumulative (Total) Confirmed Cases * & Average Daily Confirmed Cases ** $^{*}$ & Mortality Rate (\%) ${ }^{* * *}$ \\
\hline Indonesia & 56,385 & 466 & 5.1 \\
Japan & 18,600 & 123.2 & 5.2 \\
Malaysia & 8631 & 57.2 & 1.40 \\
New Zealand & 1528 & 12.3 & 1.44 \\
Singapore & 43,894 & 290.7 & $<0.1$ \\
South Korea & 12,839 & 85.0 & 2.2 \\
Vietnam & 353 & 2.34 & 0 \\
\hline
\end{tabular}

${ }^{*}, * *$ from 1 February to 30 June 2020. ${ }^{* * *}$ from 20 February to 30 June 2020. Source: Adapted from Roser et al. [14] ourworldindata.org.

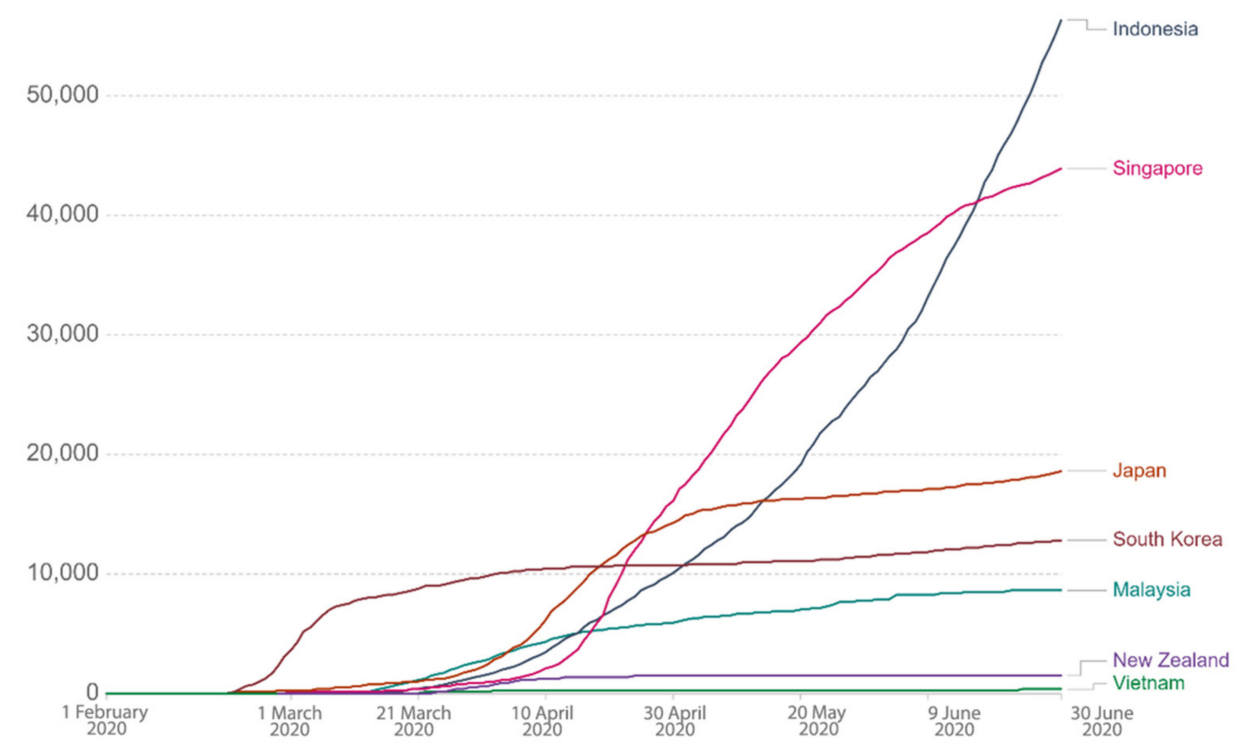

Figure 3. Cumulative COVID-19 cases. Source: Roser et al. [14]. Retrieved from ourworldindata.com.

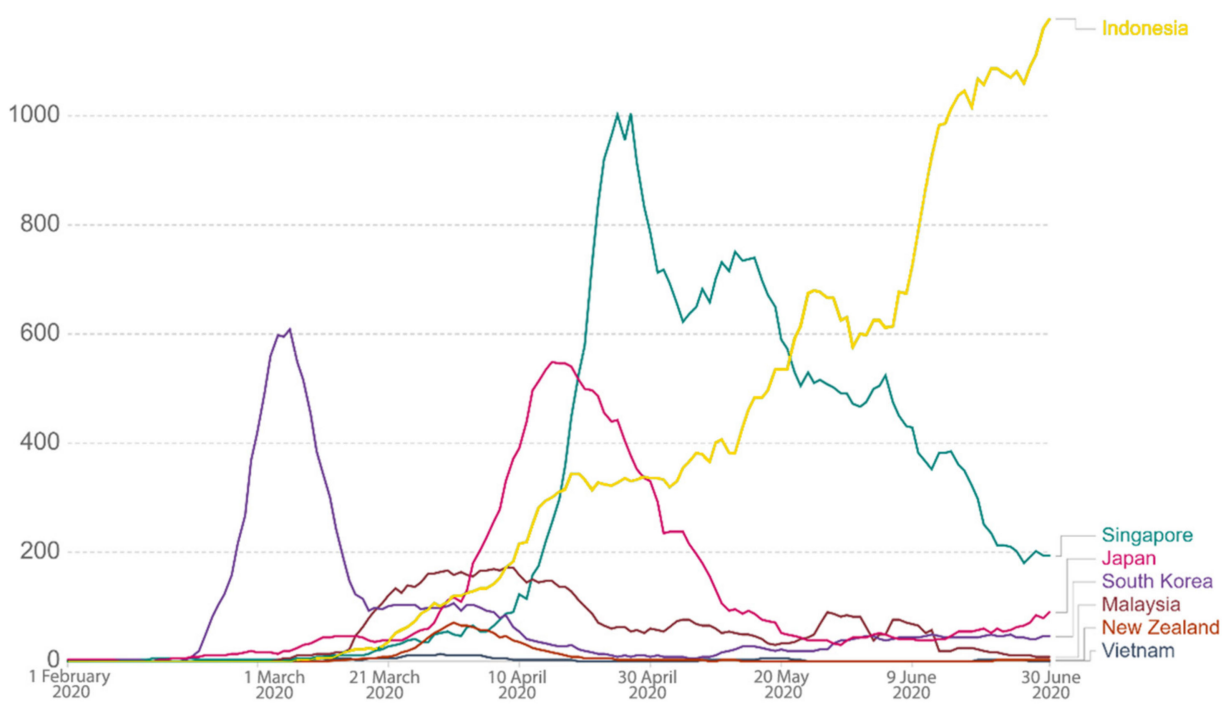

Figure 4. Daily confirmed cases (7 days average). Source: Roser et al. [14]. Retrieved from ourworldindata.com. 


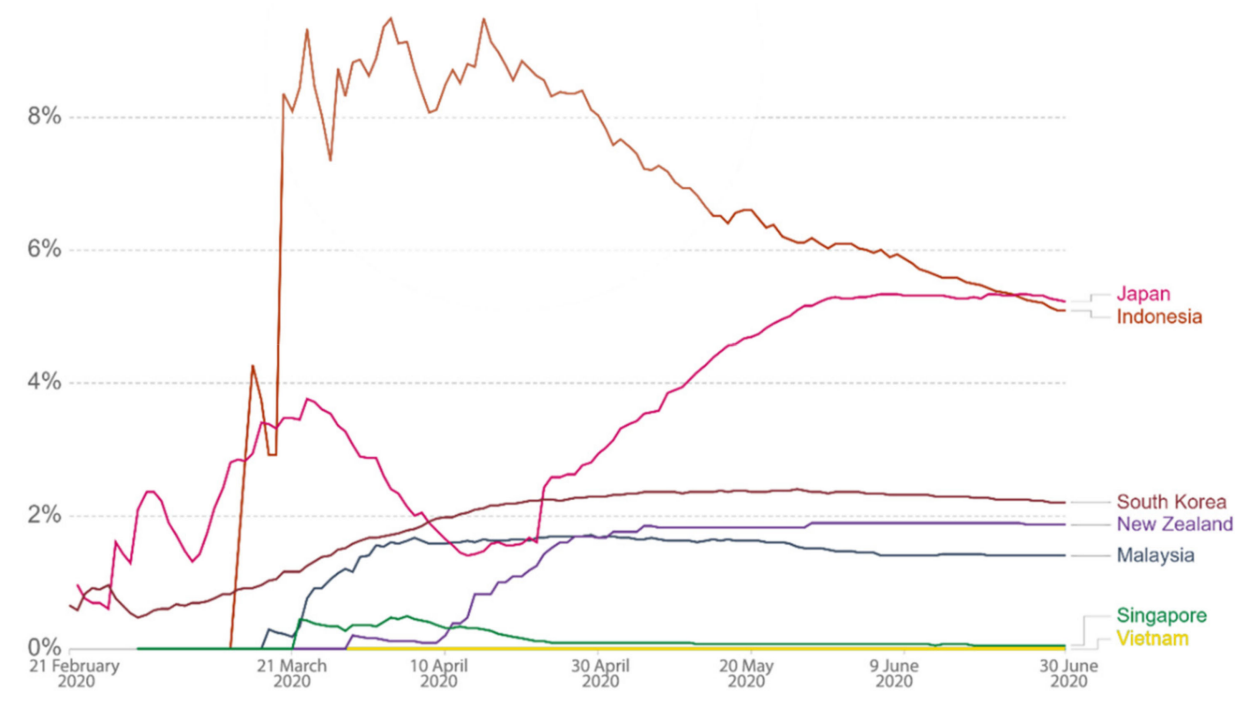

Figure 5. Mortality rates of each country. Source: Roser et al. [14]. Retrieved from ourworldindata.org.

\subsection{Data Collection}

To execute a comparative analysis across the 7 countries, we had outlined a total of 13 attributes (with 5 social attributes, 3 physical attributes, and 5 institutional attributes) and their respective sub-attributes, on the basis of the 3 primary SES factors. More precisely, the 13 exogenous factors were derived from (i) the established literature of the SES framework in commons management (e.g., types of local leadership, homogeneity level, resources/technology or facility availability) and (ii) the mainstream and relevant literature and findings of COVID in terms of potential factors that affect the pandemic. Moreover, sufficient availability of the above data or information particularly pertaining to factors influencing the pandemic was also taken into account. At the same time, the interaction arena attributes comprising the government stringency index, the health and containment index, and the economic index, which are influenced by the 13 attributes, were selected as they represent the activity levels or response effectiveness of governments that eventually determine the COVID-19 outcome. To summarize this, Table 2 illustrates an operational framework that classifies 3 SES factors that comprise attributes and sub-attributes (such as exogenous variables) and their working definitions, components within the interaction arena (activities/responses), and the success level of COVID-19 abatement (as an outcome variable).

This study made use solely of secondary sources, such as research papers, government documents/policies, official newsletters, and websites specifically pertaining to gathering COVID-19 data on the basis of the predetermined SES attributes across 7 countries; statistical data in terms of the number of COVID cases; and COVID-related research findings on factors influencing COVID-19 severity or transmission risks as well as governments' responses when dealing with the pandemic. Keywords such as "IAD-SES framework", "social-ecological system", and "COVID-19" were used on Google Scholar to garner information. Other than this, we also referred to ourworldindata.org to collect statistical data on cumulative cases, mortality rates, and the average daily confirmed cases. Moreover, prior to explaining the COVID-19 (abatement success level) outcome of a country, on the basis of the Oxford COVID-19 Government Response Tracker (OxCGRT) numerical data, we also referred to the 18 policy indicators of government responses categorized into 3 main indices, namely, the Government Response Stringency Index (on containment and closure policies, such as school closures and restrictions in movement), the Health and Containment Index (on COVID-19 testing regime or emergency investments into healthcare), and the Economic Index (on income support to citizens or provision of foreign aid), as they served as an important data input for the "interaction or action arena" (responses) of the SES framework to ensure the coherency and validity of the data (i.e., attribute input-influencing factors). 
However, it is worth noting that the data extracted only cover information from the month of February 2020 to June 2020. The specific timeframe was chosen as most country cases were at their peak.

Table 2. An operational framework comprising list of attributes, its working definitions, and effects towards COVID19 abatement.

\begin{tabular}{|c|c|c|}
\hline Factors & Attributes & $\begin{array}{l}\text { Working Definitions } \\
\text { (Sub-Attributes) }\end{array}$ \\
\hline & Low population density & $\begin{array}{c}\text { Number of population per land } \\
\text { area/size of a country }[25,26]\end{array}$ \\
\hline \multirow{3}{*}{ Social } & High social homogeneity & $\begin{array}{l}\text { Homogeneity in terms of } \\
\text { socio-cultural and demographic } \\
\text { context (e.g., background, interest, } \\
\text { ethnicity, and language) [27] }\end{array}$ \\
\hline & & \\
\hline & $\begin{array}{l}\text { High level of trust } \\
\text { among citizens }\end{array}$ & $\begin{array}{l}\text { Trust level between the community } \\
\text { and governments measured by } \\
\text { effective communication and } \\
\text { government's capability }[28,29]\end{array}$ \\
\hline
\end{tabular}

Assumptions/Effects towards COVID-19

With lower population density, it may have a lower risk of COVID-19 transmission considering more spacious environment for less close human interaction. High population density tends to be associated with the overcrowding issue, and this may likely lead to decreases in the quality of living conditions and sanitation, and thus the transmission rate may be high.

With higher social homogeneity, it may result in the higher cooperation level among the people and less self-interest among the community, emphasising collective interest and thus the higher level of COVID-19 abatement.

With a higher level of trust between the community and the government in terms of governments' capability in handling the pandemic and effective communication, there may be higher compliance to government rules, and therefore better COVID-19 abatement.

\begin{tabular}{cc}
\hline $\begin{array}{c}\text { Sufficient local management } \\
\text { knowledge and experience }\end{array}$ & $\begin{array}{c}\text { Taking into account previous } \\
\text { contagions, e.g., SARS, MERS, and } \\
\text { H1N1 that have similar features as } \\
\text { COVID-19 [30] }\end{array}$ \\
\hline $\begin{array}{c}\text { Effective foreign } \\
\text { worker containment }\end{array}$ & $\begin{array}{c}\text { Special containment measures and } \\
\text { environments in terms of } \\
\text { accommodation and facilities } \\
\text { provided for foreign workers to } \\
\text { avoid local cluster outbreak [31] }\end{array}$ \\
$\begin{array}{c}\text { High adequacy of } \\
\text { facilities [32] }\end{array}$ & $\begin{array}{c}\text { This attribute covers the density } \\
\text { of physician }\end{array}$ \\
(per 10,000) and healthcare facilities
\end{tabular}

With the past experiences and knowledge in dealing with previous pandemics, a nation (the government and the people) may have better abatement strategies.

Effective foreign worker containment via specific measures can have a lower transmission risk and thus better COVID-19 abatement.

Countries with a sufficient number of physician and healthcare facilities signifying high mobility of those facilities for COVID-19 treatment can better abate the pandemic.

Concerning whether a country is equipped with high technological tools and facilities in dealing with

Physical/ resources
High technology availability [33]
COVID-19, including contact

tracing application, testing policy, test kit production, ventilator

production, PPE production

High economic performance [31]
Considering the GNI per capita of a country, which determine the economic status by the World Bank
It is hypothesized that a country equipped with high technological facilities and tools can cope better with the pandemic in terms of providing timely and sufficient treatment for patients.
High-income countries that signify high economic performance in terms of GNI per capita can cope better with the pandemic by providing financial relief and more efficient technological/facility support. 
Table 2. Cont.

\begin{tabular}{|c|c|c|c|}
\hline Factors & Attributes & $\begin{array}{l}\text { Working Definitions } \\
\text { (Sub-Attributes) }\end{array}$ & $\begin{array}{c}\text { Assumptions/Effects towards COVID-19 } \\
\text { Abatement (Outcome) }\end{array}$ \\
\hline \multirow{5}{*}{$\begin{array}{l}\text { Governance/ } \\
\text { institutional }\end{array}$} & $\begin{array}{l}\text { Presence of top-down } \\
\text { leadership [34] }\end{array}$ & $\begin{array}{c}\text { Measured by the Democracy Index } \\
\text { (based on the types of government } \\
\text { leadership-democratic } \\
\text { or authoritarian). }\end{array}$ & $\begin{array}{l}\text { Countries with strong or firm (autocratic) } \\
\text { leadership presence can better ensure } \\
\text { compliant behaviours (i.e., better } \\
\text { cooperation among citizens) and therefore } \\
\text { better COVID-19 abatement. }\end{array}$ \\
\hline & Strict penalty [35] & $\begin{array}{l}\text { Some form of punishment or fine } \\
\text { is imposed on several conditions, } \\
\text { namely, fleeing quarantine, } \\
\text { violating lockdown, incompliance } \\
\text { with the government order, not } \\
\text { wearing mask at public areas, and } \\
\text { spreading fake news }\end{array}$ & $\begin{array}{l}\text { Countries with penalty imposition on } \\
\text { violators may have a better control of the } \\
\text { pandemic. It is believed that with this } \\
\text { stringent imposition, self-interest } \\
\text { behaviour of an individual can be } \\
\text { discouraged and thus prosocial } \\
\text { (compliant) behaviour towards collective } \\
\text { interest can be promoted, which is better } \\
\text { for COVID-19 abatement }\end{array}$ \\
\hline & $\begin{array}{l}\text { Strict lockdown } \\
\text { imposition [36-39] }\end{array}$ & $\begin{array}{l}\text { Lockdown imposition covers } \\
\text { school closure, border closure, } \\
\text { gathering bans, work from home } \\
\text { policy, national lockdown, } \\
\text { localized lockdown, and } \\
\text { military enforcement }\end{array}$ & $\begin{array}{l}\text { Countries with strict lockdown } \\
\text { enforcement limiting certain non-essential } \\
\text { activities (lesser human interactions) can } \\
\text { help stem local transmission risks and } \\
\text { thus reduce daily confirmed cases or } \\
\text { fatality rates. }\end{array}$ \\
\hline & $\begin{array}{l}\text { Strict standard of procedure in } \\
\text { public areas }[40,41]\end{array}$ & $\begin{array}{l}\text { Mask-wearing, social distancing, } \\
\text { health checks and } \\
\text { temperature scanning }\end{array}$ & $\begin{array}{l}\text { Countries with strict standard of } \\
\text { procedure imposition, especially in public } \\
\text { areas, for promoting effective monitoring } \\
\text { and reducing transmission risks can help } \\
\text { curb the pandemic. }\end{array}$ \\
\hline & $\begin{array}{l}\text { Emergency response plan and } \\
\text { COVID-19 testing policy [42] }\end{array}$ & $\begin{array}{l}\text { This attribute emphasizes } \\
\text { economy stimulus, } \\
\text { repurposing of existing buildings } \\
\text { into healthcare facilities, and the } \\
\text { COVID-19 testing policy (i.e., } \\
\text { whether the test is required by } \\
\text { anyone with symptoms or } \\
\text { without symptoms) }\end{array}$ & $\begin{array}{l}\text { Countries that provide economy stimulus } \\
\text { for its citizens for livelihood purposes can } \\
\text { help curb the local transmission risk, and } \\
\text { countries with a plan to repurpose some } \\
\text { buildings into healthcare for } \\
\text { accommodating and treating more } \\
\text { patients can help reduce transmission } \\
\text { risks and daily cases or mortality rate. } \\
\text { Countries adopting a more } \\
\text { inclusive/comprehensive COVID-19 } \\
\text { testing policy can detect cases earlier and } \\
\text { control the spread more effectively. }\end{array}$ \\
\hline \multirow{3}{*}{$\begin{array}{l}\text { Action arena } \\
\text { (activities/ } \\
\text { response } \\
\text { effectiveness } \\
\text { level for } \\
\text { the period } \\
\text { between } 1 \\
\text { February and } \\
30 \text { June 2020) }\end{array}$} & $\begin{array}{l}\text { Government Stringency } \\
\text { Index }[18,43]\end{array}$ & $\begin{array}{l}\text { This index is about containment } \\
\text { and closure policies, such as school } \\
\text { closures and restrictions } \\
\text { in movement }\end{array}$ & \multirow{3}{*}{$\begin{array}{l}\text { These three indices reflecting the } \\
\text { governments' activities and response } \\
\text { effectiveness, determined by the attributes } \\
\text { define the outcome (i.e., the COVID-19 } \\
\text { abatement level). High stringency, } \\
\text { containment, and economic support } \\
\text { indices are associated with the higher } \\
\text { success level of COVID-19 abatement. }\end{array}$} \\
\hline & $\begin{array}{l}\text { Health and Containment } \\
\text { Index }[18,43]\end{array}$ & $\begin{array}{l}\text { This is about COVID-19 testing } \\
\text { regime or emergency investments } \\
\text { into healthcare }\end{array}$ & \\
\hline & $\begin{array}{l}\text { Economic Support } \\
\text { Index }[18,43]\end{array}$ & $\begin{array}{l}\text { This is about income support to } \\
\text { citizens or provision of foreign aid }\end{array}$ & \\
\hline Outcome & $\begin{array}{l}\text { COVID-19 abatement success } \\
\text { level for the period between } \\
1 \text { February and } \\
30 \text { June } 2020[17,18,44]\end{array}$ & $\begin{array}{l}\text { Determined by three indicators, } \\
\text { namely, (i) cumulative cases, (ii) } \\
\text { average daily cases, and (iii) } \\
\text { mortality rates }\end{array}$ & $\begin{array}{l}\text { The higher the number of the three } \\
\text { indicators (i.e., high cumulative cases, } \\
\text { mortality rate, and average daily cases), } \\
\text { determined by the abovementioned } \\
\text { attributes and interaction activities, the } \\
\text { lower the success level of COVID-19 } \\
\text { abatement and vice versa. }\end{array}$ \\
\hline
\end{tabular}




\subsection{Data Analysis}

The study primarily employed a qualitative content analysis to study institutionalsocial-ecological attributes using Ostrom's 8 design principles [6] as one of the theoretical underpinnings. To aid the comparative analysis, we constructed a coding system, based on both textual and quantitative evidence, and used it to determine IAD-based SES attribute occurrence in each country, meaning that each attribute was assigned with a code on the basis of the ratio or percentage of DP/attribute presence/occurrence [45], i.e., mostly absent/absent (A) (with 0-29\%), sometimes/partially present (PP) (with 30-69\%), or mostly present or present $(\mathrm{P})$ (with $70-100 \%$ ). This coding process, particularly for the comparative analysis of a limited number of cases where a statistical inferential analysis is not possible, is scientifically appropriate and relevant since it is based on several SES scholars' systematic methodologies that have been widely applied in different resource management contexts [46-48]. Ultimately, in line with Ostrom's successful commons governance focusing on the importance of the presence of design principles, a higher frequency/co-occurrence of P indicates a better COVID-19 containment and therefore a higher success rate of the country, while a lower count of $\mathrm{P}$ connoting a higher frequency of A or PP means otherwise. Moreover, a quantitative method, apart from providing the percentage of DP occurrence and assessing the frequency of attributes present as well as for the purpose of calculating scores and assigning ranks was also used to supplement the qualitative analysis. To ensure the consistency or credibility of the coding process between two coders, we conducted inter-rater reliability of Cohen's kappa using SPSS for the reliability of all 12 SES attributes (excluding effective foreign worker containment) across 7 countries where, instead of seven items per attribute which are inadequate in terms of the minimum sample size, altogether 84 items were analyzed. The cut-off point for substantial or good reliability/agreement is $0.61-0.80$ [49,50]. Next, the 3 indices that form the interaction arena (government responses), in terms of the scores, were assigned with different codes, namely, high (H), medium (M), and low (L) (see Table 3). Since the data for each index varied from time to time, the highest score was considered when assigning the code, instead of an average score; considering the countries' different COVID-19 severity levels and situations that affect the indices, using the latter may not be accurate as it probably understates the true level or index of a country.

Table 3. A scoring range and outcome for the Government Stringency Index, the Health and Containment Index, and the Economic Support Index.

\begin{tabular}{cc}
\hline Score & Outcome \\
\hline$>90$ & High \\
$70-89$ & Medium \\
$<70$ & Low \\
\hline
\end{tabular}

At the same time, the success level of a country (outcome), influenced by the above DPs and 3 indices, was measured and determined on the basis of the total scores obtained from the 3 criteria, namely, the cumulative number of cases of each country, average daily confirmed cases, and the mortality rate of the country $[17,44]$. More precisely, the total scores were calculated based on the ranking among the 7 countries (i.e., first to seventh) and values assigned (from 1 to 7 ) to each criterion. Table 4 summarizes the options of values for each rank as well as the score ranges (from 3 to 21) for the high, medium, and low outcomes. 
Table 4. Values for each rank and the range of score determining the outcome.

\begin{tabular}{cccc}
\hline Rank & Value & Score & Outcome \\
\hline First & 7 & $16-21$ & High \\
Second & 6 & $10-15$ & Medium \\
Third & 5 & $3-9$ & Low \\
Fourth & 4 & & \\
Fifth & 3 & & \\
Sixth & 2 & & \\
Seventh & 1 & & \\
\hline
\end{tabular}

\section{Results and Discussions}

On the basis of the analysis, we show in Table 5 a summarized result spanning seven countries with respective SES attributes and interactions, as well as the success level of abatement. On the whole, with the overall kappa reliability of 0.76 where $p<0.01$, the coding of 84 items under the $12 \mathrm{SES}$ attributes was considered substantially reliable. It was found that in terms of the ranking and scoring values, only Vietnam and New Zealand, with scores $\geq 16$, were deemed successful or had high success in terms of COVID-19 abatement, while Japan and Indonesia were deemed the least successful countries in abating the pandemic, with scores less than 10. The remaining three countries, namely, Malaysia, Singapore, and South Korea, were considered to be at the medium level. For the presence or occurrence level/frequency of SES attributes, New Zealand and Singapore had the highest number of Ps, (i.e., eight Ps and one A), followed by Vietnam (with seven Ps and one A) and South Korea (with six Ps and one A). While Malaysia had scored the most PPs (i.e., eight), Indonesia and Japan had the highest number of As, i.e., at least two As for the SES attributes. From this result, we found that the SES design principle/attribute presence level appeared to be associated with the three indices on the government activity and response level, which therefore help explain the success level of COVID-19 abatement. Generally, countries with a higher number of Ps for SES attributes were more likely to score at a medium or high level for the overall three indices (e.g., New Zealand, South Korea, Singapore), except for Vietnam, with the high number of Ps having scored a low level for the economic index. The prevalence of association between attribute occurrence and the index level was even more prominent for countries such as Japan and Indonesia that had the lowest number of Ps or highest number of As for the SES attributes, where this tended to be associated with the low-level indices. The level of indices (whether it was high, medium, or low) reasonably determined by the co-occurrence of SES attributes consequently explained the abatement success level of a country in terms of the number of infections (daily average and cumulative) as well as mortality rate; the higher the level of indices, particularly for the Government Stringency Index and the Health And Containment Index, the higher the success level of a country in abating the pandemic (see Vietnam and New Zealand) and vice versa. More detailed explanations of results for each country in terms of each SES attribute are provided later.

\subsection{Low Population Density}

In a study performed by Kadi and Khelfaoui in Algeria, the authors found that population density indeed played a role in the transmission of the virus [51]. This is also supported by a study done by Bhadra et al. in different districts of India [26]. However, it cannot be a strong explanatory factor as to why the number of cases are as known [52]. Among the seven countries, based on the rank-size rule, distributing population density into 3 categories, Singapore, coded A, has the highest population density (8358 per $\mathrm{km}^{2}$ ), as shown in Table 5. Despite the high population density, the country, having adequate facilities and economic strength, managed to keep the number of positive cases and the death rate under control. In contrast, Indonesia fumbled, despite having a lower population density; this is probably due to other SES factors, such as shortage of healthcare facilities, 
weak institutional arrangement for strict enforcement, and also economic conditions as one of the considerations.

Table 5. A comparative analysis of institutional-social-ecological attributes for explaining the seven countries' interaction and outcome.

\begin{tabular}{|c|c|c|c|c|c|c|c|}
\hline $\begin{array}{c}\text { IAD-Based SES } \\
\text { Exogenous Attributes }\end{array}$ & Indonesia & Japan & Malaysia & New Zealand & Singapore & South Korea & Vietnam \\
\hline \multicolumn{8}{|c|}{ Community/social attributes } \\
\hline $\begin{array}{l}\text { Low population } \\
\text { density }\end{array}$ & $\begin{array}{l}274.2 \text { million } \\
(2020) \\
151 \text { per km² } \\
(2020) \\
P\end{array}$ & $\begin{array}{l}126.5 \text { million } \\
(2020) \\
347 \text { per km² } \\
(2020) \\
\text { PP }\end{array}$ & $\begin{array}{l}32.5 \text { million } \\
(2020) \\
99 \text { per km² }^{2} \\
(2020) \\
P\end{array}$ & $\begin{array}{l}4.886 \text { million } \\
(2020) \\
18 \text { per km² } \\
(2020) \\
\mathrm{P}\end{array}$ & $\begin{array}{l}5.6 \text { million } \\
(2020) \\
8358 \text { per km }{ }^{2} \\
(2020) \\
\text { A }\end{array}$ & $\begin{array}{l}51 \text { million } \\
(2020) \\
527 \text { per km² } \\
(2020) \\
\text { A }\end{array}$ & $\begin{array}{l}97 \text { million } \\
(2020) \\
314 \text { per km² } \\
(2020) \\
\text { PP }\end{array}$ \\
\hline $\begin{array}{c}\text { High social } \\
\text { homogeneity }\end{array}$ & $\mathrm{PP}$ & $\mathrm{P}$ & $\mathrm{PP}$ & $\mathrm{PP}$ & $\mathrm{PP}$ & $\mathrm{P}$ & $\mathrm{P}$ \\
\hline High level of trust & $\mathrm{PP}$ & $\mathrm{A}$ & $\mathrm{PP}$ & $\mathrm{P}$ & $\mathrm{P}$ & $\mathrm{PP}$ & $\mathrm{P}$ \\
\hline $\begin{array}{c}\text { Sufficient local } \\
\text { management } \\
\text { knowledge and } \\
\text { experience }\end{array}$ & $\mathrm{PP}$ & A & $\mathrm{P}$ & $\mathrm{PP}$ & $\mathrm{PP}$ & $\mathrm{P}$ & PP \\
\hline $\begin{array}{l}\text { Effective foreign } \\
\text { workers influx } \\
\text { containment }\end{array}$ & $\mathrm{N} / \mathrm{A}$ & $\mathrm{N} / \mathrm{A}$ & $\mathrm{A}$ & $\mathrm{N} / \mathrm{A}$ & $\mathrm{PP}$ & $\mathrm{N} / \mathrm{A}$ & $\mathrm{N} / \mathrm{A}$ \\
\hline \multicolumn{8}{|c|}{ Physical system attributes } \\
\hline High facility adequacy & $\mathrm{A}$ & $\mathrm{P}$ & $\mathrm{PP}$ & $\mathrm{P}$ & $\mathrm{P}$ & $\mathrm{P}$ & $\mathrm{PP}$ \\
\hline $\begin{array}{l}\text { High technology } \\
\text { availability }\end{array}$ & $\mathrm{P}$ & $\mathrm{P}$ & PP & PP & $\mathrm{P}$ & $\mathrm{P}$ & $\mathrm{P}$ \\
\hline $\begin{array}{l}\text { High economic } \\
\text { Performance }\end{array}$ & PP & $\mathrm{P}$ & PP & $\mathrm{P}$ & $\mathrm{P}$ & $\mathrm{P}$ & A \\
\hline \multicolumn{8}{|c|}{ Governance/institution attributes } \\
\hline $\begin{array}{l}\text { Local (top-down) } \\
\text { leadership }\end{array}$ & $\mathrm{PP}$ & $\mathrm{PP}$ & $\mathrm{PP}$ & A & PP & PP & $\mathrm{P}$ \\
\hline Penalty & $\mathrm{PP}$ & $\mathrm{A}$ & $\mathrm{P}$ & $\mathrm{P}$ & $\mathrm{P}$ & $\mathrm{P}$ & $\mathrm{P}$ \\
\hline Strict lockdown & $\mathrm{PP}$ & $\mathrm{A}$ & $\mathrm{P}$ & $\mathrm{P}$ & $\mathrm{P}$ & $\mathrm{PP}$ & $\mathrm{P}$ \\
\hline $\begin{array}{l}\text { Strict standard of } \\
\text { procedure in public } \\
\text { areas }\end{array}$ & $\mathrm{P}$ & $\mathrm{PP}$ & PP & $\mathrm{P}$ & $\mathrm{P}$ & PP & $\mathrm{P}$ \\
\hline $\begin{array}{l}\text { Emergency response } \\
\text { plan and COVID-19 } \\
\text { testing policies }\end{array}$ & A & $\mathrm{PP}$ & $\mathrm{PP}$ & $\mathrm{P}$ & $\mathrm{P}$ & $\mathrm{PP}$ & PP \\
\hline $\begin{array}{l}\text { Frequency or } \\
\text { co-occurrence of } \\
\text { attributes }\end{array}$ & $\begin{array}{l}3 \mathrm{Ps} \\
7 \mathrm{PPs} \\
2 \mathrm{As}\end{array}$ & $\begin{array}{l}4 \mathrm{Ps} \\
4 \mathrm{PPs} \\
4 \mathrm{As}\end{array}$ & $\begin{array}{l}4 \mathrm{Ps} \\
8 \mathrm{PPs} \\
1 \mathrm{~A}\end{array}$ & $\begin{array}{l}8 \mathrm{Ps} \\
3 \mathrm{PPs} \\
1 \mathrm{~A}\end{array}$ & $\begin{array}{l}8 \mathrm{Ps} \\
4 \mathrm{PPs} \\
1 \mathrm{~A}\end{array}$ & $\begin{array}{l}6 \mathrm{Ps} \\
5 \mathrm{PPs} \\
1 \mathrm{~A}\end{array}$ & $\begin{array}{l}7 \mathrm{Ps} \\
4 \mathrm{PPs} \\
1 \mathrm{~A}\end{array}$ \\
\hline \multicolumn{8}{|c|}{ Interaction arena (effectiveness of response/activities) } \\
\hline Stringency Index & $\begin{array}{c}80 \\
\text { Medium }\end{array}$ & $\begin{array}{c}47 \\
\text { Low }\end{array}$ & $\begin{array}{c}75 \\
\text { Medium }\end{array}$ & $\begin{array}{c}96 \\
\text { High }\end{array}$ & $\begin{array}{c}76 \\
\text { Medium }\end{array}$ & $\begin{array}{c}82 \\
\text { Medium }\end{array}$ & $\begin{array}{c}96 \\
\text { High }\end{array}$ \\
\hline $\begin{array}{c}\text { Health and } \\
\text { Containment Index }\end{array}$ & $\begin{array}{c}69 \\
\text { Low }\end{array}$ & $\begin{array}{c}41 \\
\text { Low }\end{array}$ & $\begin{array}{c}71 \\
\text { Medium }\end{array}$ & $\begin{array}{c}79 \\
\text { Medium }\end{array}$ & $\begin{array}{c}73 \\
\text { Medium }\end{array}$ & $\begin{array}{c}74 \\
\text { Medium }\end{array}$ & $\begin{array}{c}85 \\
\text { Medium }\end{array}$ \\
\hline $\begin{array}{l}\text { Economic Support } \\
\text { Index }\end{array}$ & $\begin{array}{c}25 \\
\text { Low }\end{array}$ & $\begin{array}{c}75 \\
\text { Medium }\end{array}$ & $\begin{array}{c}75 \\
\text { Medium }\end{array}$ & $\begin{array}{c}62 \\
\text { Low }\end{array}$ & $\begin{array}{c}100 \\
\text { High }\end{array}$ & $\begin{array}{c}50 \\
\text { Low }\end{array}$ & $\begin{array}{c}25 \\
\text { Low }\end{array}$ \\
\hline \multicolumn{8}{|l|}{$\begin{array}{c}\text { Outcome } \\
\text { (rank) }\end{array}$} \\
\hline Cumulative cases & $\begin{array}{l}56,385 \\
(7 \mathrm{th})\end{array}$ & $\begin{array}{c}18,600 \\
\text { (5th) }\end{array}$ & $\begin{array}{l}8631 \\
\text { (3rd) }\end{array}$ & $\begin{array}{l}1528 \\
\text { (2nd) }\end{array}$ & $\begin{array}{l}43,894 \\
\text { (6th) }\end{array}$ & 12,839 (4th) & $\begin{array}{l}353 \\
(1 \mathrm{st})\end{array}$ \\
\hline Average daily cases & $\begin{array}{l}466 \\
\text { (7th) }\end{array}$ & $\begin{array}{l}123.2 \\
(5 \mathrm{th})\end{array}$ & $\begin{array}{l}57.2 \\
\text { (3rd) }\end{array}$ & $\begin{array}{l}12.3 \\
\text { (2nd) }\end{array}$ & $\begin{array}{l}290.7 \\
\text { (6th) }\end{array}$ & $\begin{array}{l}85.0 \\
(4 \mathrm{th})\end{array}$ & $\begin{array}{l}2.34 \\
\text { (1st) }\end{array}$ \\
\hline Mortality rates & $\begin{array}{l}5.1 \% \\
\text { (6th) }\end{array}$ & $\begin{array}{l}5.2 \% \\
\text { (7th) }\end{array}$ & $\begin{array}{l}1.4 \% \\
\text { (3rd) }\end{array}$ & $\begin{array}{l}1.44 \% \\
(4 \mathrm{th})\end{array}$ & $\begin{array}{l}<0.1 \% \\
(2 \mathrm{nd})\end{array}$ & $\begin{array}{l}2.2 \% \\
\text { (5th) }\end{array}$ & $\begin{array}{l}0.0 \% \\
\text { (1st) }\end{array}$ \\
\hline Scores & 4 & 7 & 15 & 16 & 10 & 11 & 21 \\
\hline $\begin{array}{l}\text { Success level of } \\
\text { COVID-19 } \\
\text { abatement }\end{array}$ & Low & Low & Medium & High & Medium & Medium & High \\
\hline
\end{tabular}




\subsection{High Social Homogeneity}

As seen in Table 5 above, Vietnam, South Korea, and Japan were justified as P because their populations appear to be relatively homogenous in terms of culture and some demographic attributes (e.g., ethnics and language). Meanwhile, other countries were considered as PP due to their heterogeneity in terms of multicultural and racial settings, such as Malaysia, Indonesia, New Zealand, and Singapore. Culturally, Japanese people have always upheld a high standard of hygiene and obedience (compliance). They have always practiced social distancing as they respect personal space. Wearing masks when feeling sick is a norm to prevent passing a virus to others [53]. Hence, there are no objections among its citizens when mask rules were enforced by the government. However, to posit the idea that the homogeneity of a nation contributes positively to the rate of success seems rather farfetched as the analysis showed that it does not play a major role.

\subsection{High Level of Trust}

Table 6 shows the level of trust among citizens towards governments of each country. Having trust from the people ensures that the public follows the rules undisputedly (i.e., higher compliance), allowing the leaders to convince them of mass testing and quarantines before things become worse and hence keeping the virus at bay earlier on [29]. In other words, having citizens' high trust towards the government may contribute positively to the success level of a country in curbing the pandemic. For example, countries such as Singapore and New Zealand are deemed to have trust due to transparency and the leader's excellent risk communication. Meanwhile, other countries' governments (Malaysia, South Korea, and Vietnam) had constantly proven their competency, hence garnering public trust in their capabilities $[24,29,31,54,55]$. In Vietnam, the people believe that the government is working for the betterment of the country; the Vietnamese government is also competent in providing prompt communication and medical supplies, thus allowing them to carry out strategies similar to wealthier countries despite being a lower income nation [29].

Table 6. Citizen's trust towards the government handling the pandemic.

\begin{tabular}{|c|c|c|c|c|c|c|c|}
\hline & Indonesia & Japan & Malaysia & New Zealand & Singapore & South Korea & Vietnam \\
\hline $\begin{array}{c}\text { Percentage } \\
\text { perceiving } \\
\text { government as } \\
\text { untruthful [56] }\end{array}$ & 0.486 & 0.602 & 0.165 & 0.024 & $\begin{array}{l}\text { Between } 0.083 \\
\text { to } 0.092\end{array}$ & 0.102 & 0.029 \\
\hline $\begin{array}{c}\text { Public } \\
\text { Information } \\
\text { Campaign [18] }\end{array}$ & $\begin{array}{l}\text { Coordinated } \\
\text { information } \\
\text { campaign }\end{array}$ & $\begin{array}{c}\text { Coordinated } \\
\text { information } \\
\text { campaign }\end{array}$ & $\begin{array}{l}\text { Coordinated } \\
\text { information } \\
\text { campaign }\end{array}$ & $\begin{array}{l}\text { Coordinated } \\
\text { information } \\
\text { campaign }\end{array}$ & $\begin{array}{l}\text { Coordinated } \\
\text { information } \\
\text { campaign }\end{array}$ & $\begin{array}{l}\text { Coordinated } \\
\text { information } \\
\text { campaign }\end{array}$ & $\begin{array}{l}\text { Coordinated } \\
\text { information } \\
\text { campaign }\end{array}$ \\
\hline
\end{tabular}

Scoring 0.486 in a public survey conducted by Fetzer et al. [56], the Republic of Indonesia has been speculated to be hiding the real number of cases in the country by activists and political opponents. Japan's government too faced the same problem. The government has been labelled distrustful by the Edelman Barometer, and this was also backed up by the public survey, where the survey stated that more than half of its citizens $(60.2 \%)$ had perceived the government as being untruthful in containing the spread of COVID-19 [56]. To date, all countries practice a coordinated information campaign, which promotes effective communication between the government and citizens, allowing a twoway communication between both sides. This ensures citizens are well informed on the current state of virus spread in the country and ways to mitigate it. In certain country, this step helps solidify the government as a prominent leadership figure in the country.

\subsection{Sufficient Local Management Knowledge and Experience}

Sufficient local management knowledge and experience are mostly present in all seven countries, as seen in Table 5. These attributes take into account each country's experience in dealing with similar diseases to COVID-19, which in this case are Severe Acute Respiratory Syndrome (SARS), Middle East Respiratory Syndrome (MERS), and 
Novel Influenza A (H1N1). The outbreak of SARS, H1N1, and MERS occurred in 2003, 2009, and 2012, respectively. SARS, MERS and COVID-19 are caused by Betacoronavirus genus while Influenza A viruses lead to H1N1. SARS and MERS possessed a lower transmission risk but significantly higher fatality rates [57]. As for H1N1, it has been classified as having a self-limited mild-to-moderate transmission risk, although there have been reports of fatal outcomes [58].

These experiences helped certain countries better prepare and improve a healthcare system in infection prevention and control, activate response protocols, increase number of thermal scanners at all borders, and realize the importance of isolating infected cases and quarantine measures $[54,59,60]$. This means that countries with the past experiences and knowledge in handling related pandemic contagions can cope better with COVID-19. Contrary to other countries (e.g., New Zealand, South Korea, Vietnam, and Malaysia) who have experienced at least two pandemics, Japan has comparatively less past experiences (i.e., as seen in Table 7, only experiencing one pandemic). For example, in terms of its onetime H1N1 experience, Japan opted for less testing in handling the COVID-19 pandemic. This was probably due to the previous outbreak experienced by Japan that saw the public flocking to hospitals to get tested, which subsequently increased the transmission risks. Thus, the Ministry of Health, Labor and Welfare was concerned that crowded hospital lobbies would lead to a surge of COVID-19 cases and hence finalized their decision to limit accessibility [61]. Perhaps such a decision based on its limited experience may be rather ill-considered, since other countries that had experienced more than one pandemic took a different course of action (e.g., South Korea instead promoted more testing in order to curb the transmission risk). However, despite the above, in which the failure of Japan is well justified, Indonesia, coded PP similar to New Zealand, Vietnam, and Singapore, showed otherwise, where it also failed to control the pandemic. It can be deduced that this seemingly significant attribute may not necessarily be critical in explaining the severity of the pandemic.

Table 7. Countries' past experiences in handling pandemics.

\begin{tabular}{cccccccccc}
\hline Experiences in Previous Diseases & Indonesia & Japan & Malaysia & New Zealand & \multicolumn{2}{c}{ Singapore } & South Korea & Vietnam \\
\hline SARS & Yes & No & Yes & Yes & Yes & Yes & Yes \\
\hline MERS & No & No & Yes & No & No & Yes & No \\
\hline H1N1 & Yes & Yes & Yes & Yes & Yes & Yes & Yes \\
\hline
\end{tabular}

\subsection{Effective Foreign Worker Influx Containment}

Table 5 shows that both Malaysia and Singapore had a large influx of foreign workers, leading to clusters of COVID-19 cases. If there is a proper containment system of those workers, it would be indicated as P. On the other hand, other countries were marked N/A, which means this attribute was not applicable as they did not have a huge influx of foreign workers leading to COVID-19 cluster emergence. A proper containment system helps eradicate possibilities of a surge of cases, therefore controlling the number of cumulative cases and maintaining a low mortality rate.

The rise of a foreign worker cluster in Singapore was apparent from 15 to 30 March, comprising almost $61 \%$ imported cases. Both Malaysia and Singapore cited that poor living conditions had sparked a widespread infection among the group [63,64]. The severity of cases in Malaysia forced the government to employ a more stringent lockdown, called the Enhanced Movement Control Order (EMCO) [65].

\subsection{High Facility Adequacy}

In terms of determining the code in Table 5, P translates to countries with high healthcare facility adequacy, while PP translates to moderate adequacy, and A translates to a low facility adequacy. Having an ample amount of resources (physicians and facilities) 
translates to a better mobility, hence allowing more patients to be treated at one time. This would ensure better healthcare services to all. Therefore, the COVID-19 mortality rate could be lowered. Generally, high-income countries such as South Korea and Japan possessed sufficient health facilities and manpower (Table 8), except for New Zealand and Singapore that had a lower number in terms of healthcare facilities $[66,67]$. However, the lower income country like Vietnam managed to control the pandemic, probably due to its governments' swift strategy as they recognized its inability to contain a high amount of cases if the pandemic became serious [68].

Table 8. Components that affect the adequacy of facilities.

\begin{tabular}{cccccccc}
\hline & Indonesia & Japan & Malaysia & New Zealand & Singapore & South Korea & Vietnam \\
\hline $\begin{array}{c}\text { Density of } \\
\text { physician }\end{array}$ & $\begin{array}{c}3.777 \\
(2018)\end{array}$ & $\begin{array}{c}24.118 \\
(2018)\end{array}$ & $\begin{array}{l}15.132(2018) \\
\text { (per 10,000) }\end{array}$ & $\begin{array}{l}30.252(2018) \\
\text { (200) }\end{array}$ & $\begin{array}{c}23.063 \\
(2018)\end{array}$ & $23.661(2018)$ & $\begin{array}{c}8.199 \\
(2018)\end{array}$ \\
\hline $\begin{array}{c}\text { Healthcare } \\
\text { facilities }\end{array}$ & $\begin{array}{c}10.4 \text { beds } \\
(2017)\end{array}$ & $\begin{array}{c}129.8 \text { beds } \\
(2018)\end{array}$ & $\begin{array}{c}18.77 \text { beds } \\
(2017)\end{array}$ & $\begin{array}{c}25.7 \text { beds } \\
(2019)\end{array}$ & $\begin{array}{c}24.86 \text { beds } \\
(2017)\end{array}$ & $\begin{array}{c}124.3 \text { beds } \\
(2018)\end{array}$ & $\begin{array}{c}31.8 \text { beds } \\
(2013)\end{array}$ \\
\hline
\end{tabular}

Source: $[69,70]$.

Indonesia has the lowest density/number of physicians among the seven countries. In addition, its facilities are in a dire condition [71]. The country's Ministry of Health has recognized an uneven distribution of health facilities and quality across Indonesia [71,72]. Some sub-districts in Indonesia did not possess any health center and lacked necessities such as electricity, clean water, and proper equipment, with limited transportation [73]. An obvious disparity between rural areas and urban regions is common in many countries, including Malaysia. Facilities in these rural areas are usually government-funded with fewer doctors and hence a lower doctor-to-patient ratio [74].

\subsection{High Technology Availability}

The presence of technology aids governments and healthcare sectors in devising strategies towards the abatement of the virus. As seen in Table 5, countries with code P have technologically advanced medical equipment production and have also developed their own test kits. Having PP for this attribute means limited medical equipment and lacking in test kit production. All countries had also adopted the use of a contact tracing application (see Table 9). In Malaysia, the efficiency of contact tracing applications is moderate, as a study showed that the application MySejahtera uncovered 251 confirmed COVID-19 cases or 3\% of 8308 cases as of June [75].

Table 9. Technology availability for COVID-19 abatement.

\begin{tabular}{cccccccc}
\hline & Indonesia & Japan & Malaysia & New Zealand & Singapore & South Korea & Vietnam \\
\hline $\begin{array}{c}\text { Contact tracing } \\
\text { application }\end{array}$ & Yes & Yes [76] & Yes [75] & Yes [77] & Yes [31] & Yes [24] & Yes [78,79] \\
\hline $\begin{array}{c}\text { Test kit } \\
\text { production }\end{array}$ & Yes [80,81] & Yes [82] & No & No & Yes [31,83] & Yes [24] & Yes [55] \\
\hline $\begin{array}{c}\text { Ventilator } \\
\text { production }\end{array}$ & Yes [84] & Yes [85] & Yes & Yes & Yes [86] & Yes & Yes [87] \\
\hline $\begin{array}{c}\text { Personal } \\
\text { protective } \\
\text { equipment (PPE) } \\
\text { production }\end{array}$ & Yes & Yes & Yes & Yes & Yes & Yes & Yes [79] \\
\hline
\end{tabular}


Some countries had also developed their very own diagnostic kit that can detect COVID-19 to bolster testing rates in their respective country [26,50,85]. Indonesia's kits could be mass-produced with a lower budget, hence lowering expenditure [80]. Next, drive-thru testing has proven that this system is efficient, as South Korea recorded a higher testing number due to 50 drive-thru testing facilities being set up as of April 20 [54]. In addition, most countries produce their own personal protective equipment (PPE) and ventilators as global supplies dwindle and most manufacturing companies focused on meeting their own country's needs [92]. The amount of medical equipment should be proportional to the country needs to ensure all patients were given the chance to be treated and healed, thus decreasing mortality rate of the country.

\subsection{Economic Performance}

As seen in Table 10, New Zealand, Singapore, South Korea, and Japan were categorized as high-income countries. Meanwhile, Malaysia and Indonesia were grouped as upper middle-income and Vietnam as a lower middle-income country. Having immense resources based on the economic performance/status allows the government to invest in better facilities, technology, and remuneration packages that cover broad relief during the crisis, as seen in Singapore [31]. In addition, this may allow the government to exercise stringent rules and have effective enforcement. To date, Indonesia has the highest percentage of poverty among the seven countries, with half of its population struggling to make ends meet. A national lockdown may not be a preferred choice as it causes their economy to collapse, affecting their livelihood and putting tens of millions of its people who worked poorly paid informal jobs at risk [93,94]. Interestingly, despite being a lower middle-income country, which possibly undermines COVID-19 containment strategies, Vietnam, with the lowest GNI per capita rank i.e., $141^{\text {th }}$, managed to curb the pandemic successfully, with this potentially suggesting that the economic enabling factor may not have direct, significant impacts on COVID-19 outcome.

Table 10. Economic performance of the seven Asia-Pacific countries in 2019.

\begin{tabular}{cccccccc}
\hline & Indonesia & Japan & Malaysia & New Zealand & Singapore & South Korea & Vietnam \\
\hline Economic status & $\begin{array}{c}\text { Upper } \\
\text { middle- } \\
\text { income }\end{array}$ & High-income & $\begin{array}{c}\text { Upper-middle } \\
\text { income }\end{array}$ & High-income & High-income & High-income & $\begin{array}{c}\text { Lower } \\
\text { middle- } \\
\text { income }\end{array}$ \\
\hline $\begin{array}{c}\text { GNI per capita } \\
\text { (ranking based } \\
\text { on the Atlas } \\
\text { method) }\end{array}$ & $\begin{array}{c}\text { USD 4050 } \\
\left(118^{\text {th }}\right)\end{array}$ & $\begin{array}{c}\text { USD 41,690 } \\
\left(27^{\text {th }}\right)\end{array}$ & $\begin{array}{c}\text { USD 11,200 } \\
\left(68^{\text {th }}\right)\end{array}$ & $\begin{array}{c}\text { USD 42,670 } \\
\left(24^{\text {th }}\right)\end{array}$ & $\begin{array}{c}\text { USD 59,590 } \\
\left(11^{\text {th }}\right)\end{array}$ & $\begin{array}{c}\text { USD 33,720 } \\
\left(30^{\text {th }}\right)\end{array}$ & $\begin{array}{c}\text { USD 2540 } \\
\left(141^{\text {th }}\right)\end{array}$ \\
\hline
\end{tabular}

Source: $[95,96]$.

\subsection{Top-Down Leadership}

During the pandemic, the political system of each country plays a vital role in maneuvering the nation through the pandemic. Table 11 further elaborates on Table 5, explaining the local leadership status where P, PP, and A translate to authoritarian, flawed democracy, and full democracy, respectively. These labels were derived from the Economist Intelligence Unit Democracy Index, which takes into account government corruption, popular perception of citizens' freedom of choice, public confidence in the government, and the government's extent of jurisdiction [34].

Table 11. Local leadership attributes.

\begin{tabular}{cccccccc}
\hline & Indonesia & Japan & Malaysia & New Zealand & Singapore & South Korea & Vietnam \\
\hline $\begin{array}{c}\text { Democracy } \\
\text { Index }\end{array}$ & $\begin{array}{c}\text { Flawed } \\
\text { democracy }\end{array}$ & $\begin{array}{c}\text { Flawed } \\
\text { democracy }\end{array}$ & $\begin{array}{c}\text { Flawed } \\
\text { democracy }\end{array}$ & Full democracy & $\begin{array}{c}\text { Flawed } \\
\text { democracy }\end{array}$ & $\begin{array}{c}\text { Flawed } \\
\text { democracy }\end{array}$ & Authoritarian \\
\hline
\end{tabular}


In Vietnam, the role of the government is very apparent as they were authoritarian in handling the pandemic. The government is more aggressive in enforcing laws without any delay and public debate [98]. The Vietnamese government had no problem mobilizing their military for healthcare missions while enforcing strict restrictions publicly. In an effort to ensure all citizens follow the social distancing and quarantine rule, Vietnam's entrenched system of loyal neighborhood party cadres took the liberty to spy on residents and to report their sightings to the superior [68]. Such an authoritarian approach, also practiced in China, has been praised by the WHO's director general, although it seems to contravene the organization's constitution with respect to the "fundamental rights of every human being without distinction" [99]. However, New Zealand, with the Democracy Index score of full democracy, showcased excellent COVID-19 abatement. Although Kleinfield argues that types of regime do affect a country's success, this alone does not sufficiently contribute to explaining the outcome [29], and the New Zealand full democracy case is definitely worth revisiting since many scholars discovered that countries that are pro-authoritarian can control the pandemic better.

\subsection{Penalty}

Table 12 outlines the compounds imposed by the seven countries for potential offenses committed during the pandemic period. Most of the time, the amount of penalty is high to instill fear and compliance among the public. Thus, people are more inclined to adhere to the outlined Standard of Procedures (SOPs), consequently curbing the virus transmission risks. As opposed to other countries, Japan did not impose any penalty on its citizens, as summarized in Table 5. Instead, it relied heavily on the people's obedience [61,100]. The Japanese law prohibited the government from enforcing stringent penalties as it was formed on the basis of the idea that human rights should be respected. This can be linked with incidents during World War Two, wherein Japan had memories of civil rights abuse [101]. Therefore, the government can only "request" the people to minimize their movement. Social pressure is at work as the public averts risk of bearing responsibility for spreading the virus as they fear social sanctions [61].

Table 12. A breakdown of penalties employed during COVID-19.

\begin{tabular}{|c|c|c|c|c|c|c|c|}
\hline & Indonesia & Japan & Malaysia & New Zealand & Singapore & South Korea & Vietnam \\
\hline $\begin{array}{l}\text { Fleeing } \\
\text { quarantine }\end{array}$ & $\begin{array}{l}\text { 1-year/USD } \\
7116.27 \text { [102] }\end{array}$ & - & $\begin{array}{l}2 \text { years impris- } \\
\text { onment/fine, or } \\
\left.\text { both ( } 1^{\text {st }}\right) \\
5 \text { years impris- } \\
\text { onment / fine, or } \\
\text { both } \\
\text { (repeated) [103] }\end{array}$ & $\begin{array}{l}\text { USD } 2873.34 / \\
6 \text { months [104] }\end{array}$ & $\begin{array}{l}\text { Maximum USD } \\
7526.05 / \\
6 \text { months, or } \\
\text { both [105] }\end{array}$ & $\begin{array}{l}\text { Maximum USD } \\
\text { 9040.70/maximum } \\
\text { 1-year imprisonment } \\
\text { with labour [106] }\end{array}$ & $\begin{array}{l}\text { USD } 86.51 \text { to USD } \\
4235.31 \text { [107] }\end{array}$ \\
\hline $\begin{array}{l}\text { Violating } \\
\text { lockdown }\end{array}$ & 16 months [102] & - & $\begin{array}{l}2 \text { years impris- } \\
\text { onment / fine, or } \\
\text { both }\left(1^{\text {st }}\right) \\
5 \text { years impris- } \\
\text { onment / fine, or } \\
\text { both } \\
\text { (repeated) [108] }\end{array}$ & $\begin{array}{l}\text { USD 2873.34/ } \\
6 \text { months [104] }\end{array}$ & $\begin{array}{c}\text { Maximum USD } \\
7526.05 / \\
6 \text { months, or } \\
\text { both [105] }\end{array}$ & $\begin{array}{l}\text { Maximum USD } \\
\text { 9040.70/maximum } \\
\text { 1-year imprisonment } \\
\text { with labour [106] }\end{array}$ & $\begin{array}{c}\text { USD } 432.53 \\
\text { (individual), USD } \\
865.06 \\
\text { (organization)/USD } \\
\text { 4325.31 business } \\
\text { closure [107] }\end{array}$ \\
\hline $\begin{array}{l}\text { Failure } \\
\text { complying to } \\
\text { government } \\
\text { personnel }\end{array}$ & 16 months [102] & - & $\begin{array}{c}\text { USD } 2470.00 / 2 \\
\text { years, or } \\
\text { both [108] }\end{array}$ & $\begin{array}{l}\text { USD 2873.34/6 } \\
\text { months [104] }\end{array}$ & - & $\begin{array}{l}\text { Fine of USD } \\
4520.35 \text { [106] }\end{array}$ & - \\
\hline $\begin{array}{l}\text { Spreading } \\
\text { fake news }\end{array}$ & $\begin{array}{l}6 \text { years and } \\
\text { maximum of } \\
\text { USD 71.16 [109] }\end{array}$ & - & $\begin{array}{l}\text { USD } 4919.45 / \\
\text { maximum } \\
6 \text { months. Or } \\
\text { both [110] }\end{array}$ & - & $\begin{array}{l}\text { Publish notices on } \\
\text { false statements, } \\
\text { provide link to } \\
\text { government } \\
\text { website with } \\
\text { official } \\
\text { clarifications [111] }\end{array}$ & $\begin{array}{l}5 \text { years or maximum } \\
\text { fine of USD } \\
9040.70[112]\end{array}$ & $\begin{array}{c}\text { USD } \\
432.53-865.06 \text { [113] }\end{array}$ \\
\hline Mask & - & - & - & - & $\begin{array}{l}\text { USD 225.78- } \\
752.61[114]\end{array}$ & USD 893.11 [115] & $\begin{array}{l}\text { USD } 12.95 \text { for not } \\
\text { wearing and USD } \\
302.77 \text { if not } \\
\text { discarded } \\
\text { properly [107] }\end{array}$ \\
\hline
\end{tabular}




\subsection{Strict Lockdown Enforcement}

As cases spike, many countries resort to the implementation of lockdown to contain the virus from spreading. Table 13 shows that although most countries employed a strict national lockdown together with public area closures $(\mathrm{P})$, only some endorsed closure of public areas and gathering bans (PP) while others practiced little to none of them (A). Lockdown becomes more effective especially when paired up with policies of social distancing and mandatory mask wearing. It has been proven to be a great circuit breaker as it restricts movement and ensures safe proximity among citizens. Therefore, possibility of a human transmission would be low, leading to lowering cumulative cases, daily case increase, and death tolls.

Table 13. Lockdown enforcement of each country.

\begin{tabular}{|c|c|c|c|c|c|c|c|}
\hline & Indonesia & Japan & Malaysia & New Zealand & Singapore & South Korea & Vietnam \\
\hline $\begin{array}{l}\text { School } \\
\text { closure }\end{array}$ & Yes [102] & Yes [53] & Yes [23] & Yes [77] & Yes [116] & Yes [117] & Yes [78] \\
\hline $\begin{array}{l}\text { Border } \\
\text { closure }\end{array}$ & Yes & Yes [53] & Yes [23] & Yes [77] & Yes [21] & Yes [54] & Yes [78] \\
\hline $\begin{array}{l}\text { Gathering } \\
\text { bans }\end{array}$ & $\begin{array}{c}\text { Limited to } 5 \\
\text { at one } \\
\text { time [102] }\end{array}$ & Yes [53] & Yes [23] & Yes [77] & Yes [21] & Yes [54] & Yes [78] \\
\hline $\begin{array}{l}\text { Work from } \\
\text { home }\end{array}$ & Yes [118] & Yes [76] & $\begin{array}{c}\text { Yes, except } \\
\text { essential } \\
\text { workers [23] }\end{array}$ & $\begin{array}{c}\text { Yes, except } \\
\text { essential } \\
\text { services [77] }\end{array}$ & $\begin{array}{c}\text { Yes, except } \\
\text { essential } \\
\text { workers [119] }\end{array}$ & Yes [117] & Yes \\
\hline $\begin{array}{l}\text { National } \\
\text { lockdown }\end{array}$ & No [93] & No [53] & Yes [23] & Yes [120] & Yes [119] & No [117] & Yes [121] \\
\hline $\begin{array}{l}\text { Localized } \\
\text { lockdown }\end{array}$ & Yes [122] & No [123] & - & - & - & Yes [117] & - \\
\hline $\begin{array}{c}\text { Military } \\
\text { enforcement }\end{array}$ & Yes [124] & No [53] & Yes [125] & Yes & Yes [31] & $\begin{array}{c}\text { Only for } \\
\text { disinfecting } \\
\text { process }\end{array}$ & Yes $[98,126]$ \\
\hline
\end{tabular}

Source: [19,23,53-55,68,78,94,98,102,117,118,120,121,123,126,127].

In Japan, the government is incapable of enforcing lockdown due to the Japanese Law [53]. However, an amendment was made to allow the prime minister to declare a "state of emergency" in areas that are heavily inflicted by the virus. In addition, although the government had called for remote working, most companies are not equipped and prepared for such a scheme [53]. Both South Korea and Indonesia applied a national social distancing policy instead of a national lockdown (Table 13). Localized lockdowns are to only be implemented in highly infected areas [94,123]. However, the amount of comprehensive rapid testing performed by South Korea set their outcomes apart. Likely due to the poorer state of the economy, Indonesia's response was slow and unclear, which in the end cost the country a spike in cases.

\subsection{Strict Standard of Procedure in Public Areas}

Table 5 shows that most countries were coded P, with the implementation of all SOPs except for the mask-wearing requirement (see Table 14). Severe Acute Respiratory Syndrome Coronavirus 2 (SARS-CoV-2) spreads by water droplets that can be transmitted through air or on surfaces. The WHO suggested mask wearing as an integral strategy to suppress transmission coupled with other policies such as social distancing, health checks and temperature scanning in public areas, washing hands, and sterilization. Sterilization and fumigation procedures are vital in frequently used public spaces, such as public transportation stations, shops, and especially in infected venues. These SOPs are crucial as they can break the virus chain if abided accordingly, hence lowering infection cases. 
Table 14. SOPs in respective countries.

\begin{tabular}{cccccccc}
\hline & Indonesia & Japan & Malaysia & New Zealand & Singapore & South Korea & Vietnam \\
\hline Mask wearing & $\begin{array}{c}\text { Compulsory } \\
{[128]}\end{array}$ & $\begin{array}{c}\text { Habitual } \\
{[53,129]}\end{array}$ & $\begin{array}{c}\text { Recommendation } \\
{[130]}\end{array}$ & $\begin{array}{c}\text { Compulsory } \\
{[131]}\end{array}$ & $\begin{array}{c}\text { Compulsory } \\
{[119]}\end{array}$ & Habitual [54] & $\begin{array}{c}\text { Compulsory } \\
{[132]}\end{array}$ \\
\hline $\begin{array}{c}\text { Social } \\
\text { distancing }\end{array}$ & Yes [133] & Yes [76] & Yes [23] & Yes [77] & Yes [21] & Yes [117] & Yes [55] \\
\hline $\begin{array}{c}\text { Health checks } \\
\text { and temperature } \\
\text { scanning }\end{array}$ & Yes [118] & Yes [134] & Yes [23] & Yes [77] & Yes [21,31] & Yes [54] & Yes [68] \\
\hline $\begin{array}{c}\text { Mass } \\
\text { sterilization }\end{array}$ & Yes & Yes [129] & Yes & Yes [135] & Yes & Yes [54] & Yes \\
\hline
\end{tabular}

Source: $[21,23,31,53-55,68,76,77,117,118,128-135]$

Japan was assigned PP although there is implementation of SOP in public areas. This is due to the fact that these SOPs are recommended rather than enforced [53]. As stated previously, the unique Japanese law does not allow the government to impose their citizens with a strict law, instead only hoping that they will adhere to the measures.

\subsection{Emergency Response Plans and COVID-19 Testing Policies}

An emergency response plan in a pandemic situation is crucial to ensure an effective control of the pandemic. Table 5 shows that all countries had devised their own emergency response plan, although some may not be as rigorous as the others'. Among the popular forms of emergency response plan are debt relief and income support by the government, as shown in Table 15. Most countries opted for $<50 \%$ lost salary coverage with a narrow relief, applied by Indonesia, Japan, South Korea, and Vietnam. The Singapore government devised a $>50 \%$ salary coverage plan with a broad relief. Having a broad relief helps decrease the citizen's movement as they can stay home without worrying much about their financial conditions. Restricting movement proves to be an excellent circuit breaker to the virus transmission.

Table 15. Countries' emergency response plans and COVID-19 testing policies.

\begin{tabular}{|c|c|c|c|c|c|c|c|}
\hline & Indonesia & Japan & Malaysia & New Zealand & Singapore & South Korea & Vietnam \\
\hline $\begin{array}{c}\text { Economy } \\
\text { stimulus } \\
\text { (income } \\
\text { support and } \\
\text { debt/contract } \\
\text { relief) }\end{array}$ & $\begin{array}{c}\text { Covers }<50 \% \\
\text { of lost salary } \\
\text { with narrow } \\
\text { relief [18] }\end{array}$ & $\begin{array}{c}\text { Covers }<50 \% \\
\text { of lost salary } \\
\text { with narrow } \\
\text { relief [18] }\end{array}$ & $\begin{array}{c}\text { Covers }<50 \% \\
\text { of lost salary } \\
\text { with broad } \\
\text { relief [18] }\end{array}$ & $\begin{array}{c}\text { Covers }>50 \% \\
\text { of lost salary } \\
\text { with broad } \\
\text { relief [18] }\end{array}$ & $\begin{array}{c}\text { Covers }>50 \% \\
\text { of lost salary } \\
\text { with broad } \\
\text { relief [18] }\end{array}$ & $\begin{array}{c}\text { Covers }<50 \% \\
\text { of lost salary } \\
\text { with narrow } \\
\text { relief [18] }\end{array}$ & $\begin{array}{c}\text { Covers }<50 \% \\
\text { of lost salary } \\
\text { with narrow } \\
\text { relief [18] }\end{array}$ \\
\hline $\begin{array}{l}\text { Repurposing } \\
\text { buildings into } \\
\text { healthcare } \\
\text { facilities }\end{array}$ & Yes [84] & Yes [136] & Yes [23] & Yes & Yes [31] & Yes [137] & Yes $[55,138]$ \\
\hline $\begin{array}{l}\text { COVID-19 } \\
\text { testing } \\
\text { policies }\end{array}$ & $\begin{array}{l}\text { Those with } \\
\text { symptoms } \\
\text { and key } \\
\text { groups } \\
\text { only [18] }\end{array}$ & $\begin{array}{l}\text { Anyone with } \\
\text { symptoms [18] }\end{array}$ & $\begin{array}{l}\text { Open public } \\
\text { testing, } \\
\text { including } \\
\text { asymptomatic } \\
\text { individu- } \\
\text { als [18] }\end{array}$ & $\begin{array}{l}\text { Anyone with } \\
\text { symptoms [18] }\end{array}$ & $\begin{array}{l}\text { Anyone with } \\
\text { symptoms [18] }\end{array}$ & $\begin{array}{l}\text { Open public } \\
\text { testing, } \\
\text { including } \\
\text { asymptomatic } \\
\text { individu- } \\
\text { als [18] }\end{array}$ & $\begin{array}{c}\text { Open public } \\
\text { testing, } \\
\text { including } \\
\text { asymptomatic } \\
\text { individuals } \\
\text { [18] }\end{array}$ \\
\hline
\end{tabular}

Source: $[19,31,53,55,65,79,94,127,137-142]$.

As a step towards preparing for the worst, the governments also called for the increase of healthcare facilities by turning buildings into quarantine centers, mobilizing more labs for testing and research purposes $[60,136,143]$ For example, Indonesia repurposed a truck into a laboratory to increase testing rates [84]. The South Korean and Malaysian healthcare systems also transformed a few hospitals into special COVID-19 hospitals [23,137]; thus, specialized healthcare workers could prioritize treating COVID-19 patients until recovery.

Moreover, COVID-19 testing policies also play a crucial role in breaking the virus chain as the infected can be promptly identified and isolated or quarantined. Countries with a more inclusive and comprehensive swab testing policy, which conducted open 
public/mass testing covering both symptomatic and asymptomatic testing (e.g., Vietnam, New Zealand, Malaysia, South Korea) may have a better COVID-19 abatement outcome. On the other hand, countries (e.g., Indonesia) with limited swab testing, probably due to the above economic or facility availability constraints, may have a COVID-19 outcome that will become severe since many cases, especially asymptomatic ones who are also highly infectious, go undetected.

\subsection{Interaction Arena}

In addition to the SES attributes described above, activities or government response effectiveness in terms of efficient monitoring, communication, movement restriction, and extensive contact tracing and testing were used as supplemental evidence and references to further explain the COVID-19 abatement/severity outcome of each country. There are three indices referred to, namely, the Government Response Stringency Index, the Health and Containment Index, and the Economic Support Index.

New Zealand and Vietnam recorded the highest stringency score at 96, followed by South Korea at 82, Indonesia at 80, Singapore at 76, Malaysia at 75, and Japan at 47 [18]. High stringency, composed of indicators such as school and workplace closure, public events or gathering restriction, and international and domestic travel controls, reflects governments' strict policy emphasizing effective monitoring. In terms of the results, New Zealand and Vietnam were labelled as high, while Japan was considered low. Other countries such as Singapore, South Korea, Indonesia, and Malaysia were considered medium.

Meanwhile, Vietnam had the highest health and containment index with a score of 85, followed by New Zealand scoring 79, South Korea at 74, Singapore obtaining 73, Malaysia at 71, Indonesia at 69, and finally Japan at 41 [18], where in terms of the analysis, both Indonesia and Japan are considered low. The Containment and Health Index measures indicators such as testing policies (PCR tests) and extent of contact tracing. Each of these countries has varying testing policies ranging from only available to those with symptoms and key groups to open public testing that allows even asymptomatic patients to take part, as shown in Table 15. Despite having a policy that allows anyone to undergo swab testing, Japan has the second lowest swab testing frequency (of 7 days average per 1000) as of 30 June at 0.03 , coming second after Indonesia at 0.04 . Singapore has the highest average at 1.92 followed by New Zealand at 1.31, Malaysia at 0.32, South Korea at 0.22. and lastly, no data are available for Vietnam [18].

Looking into the statistics of the Economic Support Index, Singapore obtained the maximum value of 100 in providing economic support to its citizens, followed by Malaysia and Japan at 75, New Zealand at 62, South Korea at 50, and Indonesia and Vietnam at 25. The Economic Support Index illustrates the government support in terms of covering salaries, providing direct cash payments, or universal basic income or similar for the unemployed, freezing financial obligations such as loans and services [18].

Due to its financial capacity, Singapore is able to allocate a huge amount of money to ease the financial burden of its citizens. This results in having a sufficient amount of financial aid provided by the government, which lessens the need to work amidst the pandemic. Therefore, Singaporeans are able to comply to the government rules and stay home unless necessary. Thus, it is appropriate to say that the indices relate and have strong dependency with each other. This scenario differs for a country with a different economic reality. By contrast, Indonesia and Vietnam scored 25, the lowest among other countries. Indonesia, with almost $9.6 \%$ of its population living below the national poverty line, is unable to cater enough financial aid to each of its citizens. Its citizens working in informal settings with low wages are left with no choice but to work, despite stay-athome restrictions $[93,94]$.

Although financial consideration does play a big part in determining the COVID-19 abatement level of a country, it is not a major deciding factor. As seen in Table 10, Vietnam does not have an economy as robust as Singapore and yet the former managed to mitigate 
the virus earlier than its counterpart due to its efficient government response policy [68]. Vietnam, scoring a high tier in both the Government Stringency Index and the Health and Containment Index entails its government with strong leadership presence, with strict monitoring and efficient communication skill, as well as a comprehensive contact tracing policy $[51,111,131]$. Hence, citizens are well informed and possible cases can be mitigated before emerging into a deadly cluster. Despite having the lowest score among the other countries in the Economic Support Index, Vietnam is compensated by its strong government response policy. A similar scenario could be seen in New Zealand, with a financial capacity significantly lower than others. Although scoring only 62, New Zealand successfully lowered its COVID-19 cases and mortality rate approaching 30 June 2020, as seen in Table 5.

Therefore, it can be deduced that the level of COVID-19 abatement can be rather directly justified by the scores reflected in the Government Stringency Index and the Health and Containment Index. Countries scoring a high score in these indices generally have a high cumulative score, as shown in Table 5 (Vietnam and New Zealand). Meanwhile, countries with significantly lower scores in both indices had a low success rate in abating the virus. This is prominently seen in Japan, which scored low in both indices. Despite being in the medium tier in providing economic support, Japan is still struggling to control the number of COVID-19 cases in its country.

\section{Conclusions and Recommendations}

Much effort has been focused on pharmaceutical aspects in combating the COVID-19 pandemic; thus, in recognizing the gap and the need in exploring non-pharmaceutical interventions and strategies in stemming the transmission risk, this diagnostic study's primary objective was to explain COVID-19 severity from an SES perspective, hence testing out the framework's adaptability in the non-commons or health context. Through the SES analytical framework providing a theoretical basis, we reviewed seven Asia-Pacific countries for institutional-social-ecological factors that affect their success in fighting the pandemic. Probably due to adherence to, or the high presence (P) frequency of, the design principles, which subsequently reflect the high level of the Government Stringency Index and the Health and Containment Index, both Vietnam and New Zealand were classified as countries with the high success level of COVID-19 abatement, which is coherently explainable. Meanwhile, Japan and Indonesia, with low presence of $(\mathrm{P})$ frequency or with the high presence of (A), were deemed as countries with the low success level.

However, although some countries possessed a high number of Ps for SES attributes, the outcome signified that some countries (e.g., South Korea and Singapore) with the intermediate level of success may not effectively abate the pandemic in comparison with what has been hypothesized. Thus, two lessons can be drawn: (i) having high number of Ps for SES attributes does not always mean a panacea for the pandemic; however, it would be detrimental to a country if it lacks them severely, and (ii) some attributes (mostly from the governance factor) may carry higher weightage towards explaining the success level. More precisely, the critical success factors/design principles found in Vietnam and New Zealand are ultimately about the strict implementation of lockdown, penalties, high trust level of citizens towards government, highly adequate and efficient mobilized facilities, and comprehensive COVID-19 testing policy. The economic situation of a country does play a vital role in keeping the pandemic under control, but Vietnam demonstrated otherwise or is an "anomaly" in handling their COVID-19 situation, given its status as a lower middle-income nation by the World Bank. Meanwhile, low success outcome countries, such as Japan and Indonesia, seemingly are associated with the lack of national lockdown implementation and low testing rates, and specifically in Indonesia, it failed probably due to its economic situation, inadequate facilities and resources, and manpower to contain the pandemic. Other factors, such as population density, social homogeneity, past experience and knowledge in managing an infectious disease, and local leadership regimes, are not as impactful and significant as the above factors. 
By understanding the overview of SES attributes in relation to COVID-19 and identifying which are potentially the most significant ones, this comparative study, via the SES methodical coding framework, provides knowledge and best practice exchange between the seven countries, shedding light on how to leverage these critical institutional-socialecological attributes so that more strategic policy guide and coordinated measures for effective country preparedness and response in terms of managing and addressing the current and the future health crisis can be devised.

Despite the above insights and contribution, this study with a rather small number of case studies was, however, limited to secondary data and literature reviews, which were primarily analyzed in a qualitative descriptive manner. Meaning that information and conclusion (i.e., indicative patterns of significant SES attributes for COVID-19 abatement) drawn from this study may not entirely be generalizable to other countries' in curbing COVID-19 and do not provide absolute quantitative accuracy. Therefore, for further validation of the existing SES attributes in terms of how applicable and valid these factors are determining the COVID-19 severity level, future studies may consider extending the SES framework application to include more geographical regions and countries. In addition, focusing on the inclusion of higher-tier SES attributes and exploration of other non-pharmaceutical factors, cross-sectional studies via the public perception survey coupled with robust inferential statistical analyses for more accurate explanation and prediction of the pandemic outcome are necessary.

Author Contributions: G.H.T.L.: Conceptualization, Writing—review \& editing, Methodology, Supervision, Validation; N.A.b.M.S.: Writing - original draft, Writing—review \& editing, Investigation, Visualization; P.C.L.: Formal Analysis, Resources, Project administration, data curation; L.B.Y.: Methodology, review, data curation, funding acquisition; C.T.C.: Validation, Funding acquisition, Software; M.H.H.A.: Resources, funding acquisition, Supervision; A.M.R.A.M.: Visualization, data curation, funding acquisition, resources. All authors have read and agreed to the published version of the manuscript.

Funding: This research publication was funded by Universiti Teknologi Malaysia (UTM) Transdisciplinary research grant no. Q.J130000.3552.07G55.

Institutional Review Board Statement: Not applicable.

Informed Consent Statement: Not applicable.

Data Availability Statement: The data presented in this study are available in this article.

Acknowledgments: The authors would like to express their utmost gratitude to Hita Unnikrishnan for her useful feedback in the conceptualization of this paper.

Conflicts of Interest: The authors declare no conflict of interest.

\section{References}

1. World Health Organization. Q\&A on Coronaviruses (COVID-19). 2020. Available online: https://www.who.int/emergencies/ diseases /novel-coronavirus-2019/question-and-answers-hub/q-a-detail/q-a-coronaviruses (accessed on 29 August 2020).

2. Li, G.; Fan, Y.; Lai, Y.; Han, T.; Li, Z.; Zhou, P.; Pan, P.; Wang, W.; Hu, D.; Liu, X.; et al. Coronavirus infections and immune responses. J. Med. Virol. 2020, 92, 424-432. Available online: https://onlinelibrary.wiley.com/doi/abs/10.1002/jmv.25685 (accessed on 29 August 2020). [CrossRef]

3. Bryner, J. 1st known Case of Coronavirus Traced Back to November in China. Live Science. 2020. p. 1. Available online: https:/ / www.livescience.com/first-case-coronavirus-found.html (accessed on 29 August 2020).

4. Shereen, M.A.; Khan, S.; Kazmi, A.; Bashir, N.; Siddique, R. COVID-19 infection: Origin, transmission, and characteristics of human coronaviruses. J. Adv. Res. 2020, 24, 91-98. [CrossRef] [PubMed]

5. Ling, G.H.T.; Ho, C.M.C. Effects of the Coronavirus (COVID-19) Pandemic on Social Behaviors: From a Social Dilemma Perspective. Tech. Sci. J. 2020, 6, 69-87.

6. Ostrom, E. Governing the Commons; Cambridge University Press: Cambridge, UK, 1990.

7. Cole, D.H.; Epstein, G.; McGinnis, M.D. The Utility of Combining the IAD and SES Frameworks. Int. J Commons 2019, 13, 244. Available online: https:/ / www.thecommonsjournal.org/article/10.18352/ijc.864/ (accessed on 3 September 2020). [CrossRef]

8. Mcginnis, M.; Ostrom, E. Design Principles For Local And Global Commons. In Proceedings of the Linking Local and Global Commons, Cambridge, MA, USA, 23-25 April 1992. 
9. Partelow, S. A review of the social-ecological systems framework: Applications, methods, modifications, and challenges. Ecol. Soc. 2018, 23, 36. [CrossRef]

10. Ling, G.H.T.; Leng, P.C.; Ho, C.S. Effects of diverse property rights on rural neighbourhood public open space (POS) governance: Evidence from Sabah, Malaysia. Economies 2019, 7. [CrossRef]

11. Cumming, G.S. Spatial Models in Ecology and Spatial Resilience. In Spatial Resilience in Social-Ecological Systems; Springer Netherlands: Dordrecht, Netherlands, 2011.

12. Ostrom, E.; Cox, M. Moving beyond panaceas: A multi-tiered diagnostic approach for social-ecological analysis. Int. Conf. Environ. Futur. 2010, 37, 451-463. Available online: http:/ / www.cbd.int/ (accessed on 15 November 2020). [CrossRef]

13. Tashman, P. The Socioecological Systems Framework, COVID-19 and Organizations. Alliance for Research on Corporate Sustainability. Alliance for Research on Corporate Sustainability. 2020. Available online: https:/ / corporate-sustainability.org/ the-socioecological-systems-framework-covid-19-and-organizations / (accessed on 27 October 2020).

14. Raboisson, D.; Lhermie, G. Living With COVID-19: A Systemic and Multi-Criteria Approach to Enact Evidence-Based Health Policy. Front. Public Health 2019, 1. [CrossRef]

15. Wilcox, B.A.; Aguirre, A.A.; De Paula, N.; Siriaroonrat, B.; Echaubard, P. Operationalizing one health employing social-ecological systems theory: Lessons from the Greater Mekong Sub-region. Front. Public Health 2019, 7. [CrossRef]

16. McGinnis, M.D.; Ostrom, E. Social-ecological system framework: Initial changes and continuing challenges. Ecol Soc. 2014, 19, 30. [CrossRef]

17. Su, D.; Chen, Y.; He, K.; Zhang, T.; Tan, M.; Zhang, Y.; Zhang, Z. Influence of socio-ecological factors on COVID-19 risk: A cross-sectional study 1 based on 178 countries/regions worldwide. Lancet 2020. [CrossRef]

18. Roser, M.; Ritchie, H.; Ortiz-Ospina, E.; Hasell, J. Coronavirus Pandemic (COVID-19). Our World Data. 2020. Available online: https: / / ourworldindata.org/coronavirus (accessed on 3 October 2020).

19. Henrickson, M. Kiwis and COVID-19: The Aotearoa New Zealand Response to the Global Pandemic. Int. J. Community Soc. Dev. 2020, 2, 121-133. [CrossRef]

20. World Health Organization. Novel Coronavirus-Japan. 2020. Available online: https://www.who.int/csr/don/17-january-20 20-novel-coronavirus-japan-ex-china/en/ (accessed on 21 September 2020).

21. Quah, D. 11 Singapore's Policy Response to COVID-19. In: Mitigating the COVID Economic Crisis: Act Fast and Do Whatever It Takes. pp. 104-111. 2020. Available online: https:/ /voxeu.org/content/mitigating-covid-economic-crisis-act-fast-and-dowhatever-it-takes (accessed on 17 September 2020).

22. Channel News Asia. Indonesia's First 3 COVID-19 Patients Open up About Online Hate and Stigmatisation-CNA. 2020. Available online: https:/ / www.channelnewsasia.com/news/asia/online-hate-indonesia-first-3-covid-19-patients-open-up12617404 (accessed on 27 September 2020).

23. Elengoe, A. COVID-19 Outbreak in Malaysia. Osong Public Health Res. Perspect. 2020, 11, 93-100. Available online: https: //doi.org/10.24171/j.phrp.2020.11.3.08 (accessed on 12 September 2020). [CrossRef] [PubMed]

24. Levkowitz, A. South Korea's Approach to Coronavirus. BESA Center Perspectives Paper No. 1,518, 3 April 2020. Available online: https:/ / besacenter.org/perspectives-papers/south-korea-coronavirus / (accessed on 3 September 2020).

25. World Bank. Population Density (People per Sq. km of Land Area). 2019. Available online: https://data.worldbank.org/ indicator /EN.POP.DNST?end=2019\&start=1961 (accessed on 28 January 2021).

26. Bhadra, A.; Mukherjee, A.; Sarkar, K. Impact of population density on the Covid-19 infected and mortality rates in India. Model. Earth Syst. Environ. 2020. [CrossRef]

27. Varughese, G.; Ostrom, E. The Contested Role of Heterogeneity in Collective Action: Some Evidence from Community Forestry in Nepal. World Dev. 2001, 29, 747-765. Available online: www.elsevier.com/locate/worlddev (accessed on 28 January 2021). [CrossRef]

28. Han, Q.; Zheng, B.; Cristea, M.; Agostini, M.; Belanger, J.; Gutzkow, B.; Kreienkamp, J.; Leander, P. Trust in government and its associations with health behaviour and prosocial behaviour during the COVID-19 pandemic. PsyArXiv 2020. [CrossRef]

29. Kleinfeld, R. Do Authoritarian or Democratic Countries Handle Pandemics Better? Carnegie Endowment for International Peace. 2020. Available online: https: / carnegieendowment.org/2020/03/31/do-authoritarian-or-democratic-countries-handlepandemics-better-pub-81404 (accessed on 29 September 2020).

30. Altakarli, N.S. China's Response to the COVID-19 Outbreak: A Model for Epidemic Preparedness and Management Keywords Coronavirus COVID-19 Epidemic preparedness Epidemic management Outbreak response. Rev. Artic. Dubai Med. J. 2020, 3 , 44-49. Available online: www.karger.com/dmj (accessed on 28 January 2021). [CrossRef]

31. Woo, J.J. Policy capacity and Singapore's response to the COVID-19 pandemic. Policy Soc. 2020, 39, 345-362. Available online: https:/ / www.tandfonline.com/doi/abs/10.1080/14494035.2020.1783789 (accessed on 26 September 2020). [CrossRef]

32. International Labour Organization. COVID-19: Are There Enough Health Workers? International Labour Organization: Geneva, Switzerland, 2020. Available online: https://ilostat.ilo.org/covid-19-are-there-enough-health-workers/ (accessed on 28 January 2021).

33. Kumar, A.; Gupta, P.K.; Srivastava, A. A review of modern technologies for tackling COVID-19 pandemic. Diabetes Metab. Syndr. Clin. Res. Rev. 2020, 14, 569-573. [CrossRef] [PubMed] 
34. Chen, Y. Democracy in the Face of COVID-19 Have Less Democratic Countries Been More Effective at Preventing the Spread of This Pandemic? Available online: https://www.econ.berkeley.edu/sites/default/files/Final_AnnieYiChen.pdf (accessed on 27 January 2020).

35. Chae, S.H.; Park, H.J. Effectiveness of penalties for lockdown violations during the covid-19 pandemic in Germany. Am. J. Public Health 2020, 110, 1844-1849. Available online: http://ajph.aphapublications.org/ (accessed on 28 January 2021). [CrossRef] [PubMed]

36. Atalan, A. Is the lockdown important to prevent the COVID-9 pandemic? Effects on psychology, environment and economyperspective. Ann. Med. Surg. 2020, 56, 38-42. [CrossRef]

37. Lau, H.; Khosrawipour, V.; Kocbach, P.; Mikolajczyk, A.; Schubert, J.; Bania, J.; Khosrawipour, T. The positive impact of lockdown in Wuhan on containing the COVID-19 outbreak in China. J. Travel Med. 2020, 2020, 1-7. Available online: https: / / academic.oup.com/jtm/article/27/3/taaa037/5808003 (accessed on 28 January 2020). [CrossRef] [PubMed]

38. Sugiyanto, M.A. A Mathematical Model of the Covid-19 Cases in Indonesia (Under and Without Lockdown Enforcement). Biol. Med. Nat. Prod. Chem. 2020, 9, 15-19. Available online: http://sciencebiology.org/index.php/BIOMEDICH/article/view/103 (accessed on 28 January 2021). [CrossRef]

39. Aziz, N.A.; Othman, J.; Lugova, H.; Suleiman, A. Malaysia's approach in handling COVID-19 onslaught: Report on the Movement Control Order (MCO) and targeted screening to reduce community infection rate and impact on public health and economy. $J$. Infect. Public Health 2020, 13, 1823-1829. [CrossRef]

40. Howard, J.; Huang, A.; Li, Z.; Tufekci, Z.; Zdimal, V.; Van Der Westhuizen, H.-M.; Von Delft, A.; Price, A.; Fridman, L.; Tang, L.-H.; et al. An evidence review of face masks against COVID-19. Proc. Natl. Acad. Sci. USA 2021, 118, e2014564118. [CrossRef]

41. Leung, C.C.; Cheng, K.K.; Lam, T.H.; Migliori, G.B. Mask wearing to complement social distancing and save lives during COVID-19. Int. J. Tuberc. Lung. Dis. 2020, 24, 556-558. [CrossRef]

42. Jones Lang LaSalle Incorporated. How Cities Mobilized to Convert Spaces into COVID-19 Care Facilities; Jones Lang LaSalle Incorporated: Chicago, IL, USA, 2020. Available online: https://www.jll.com.my/en/trends-and-insights/cities/how-citiesmobilized-to-convert-spaces-into-covid19-care-facilities (accessed on 28 January 2021).

43. Umair, S.; Waqas, U.; Faheem, M. COVID-19 Pandemic: Stringent Measures of Malaysia and Implications for Other Countries. Postgrad. Med. J. 2020, 97, 130-132. Available online: https:/ / pubmed.ncbi.nlm.nih.gov/32561598/ (accessed on 28 January 2021). [CrossRef] [PubMed]

44. Dempere, J. A recipe to control the first wave of COVID-19: More or less democracy? Transform. Gov. People Process Policy 2021. [CrossRef]

45. Xie, Y.; Wen, Y.; Cirella, G.T. Application of Ostrom's Social-Ecological Systems Framework in Nature Reserves: Hybrid Psycho-Economic Model of Collective Forest Management. Sustainability 2019, 11, 6929. [CrossRef]

46. Faggin, J.M.; Behagel, J.H.; Arts, B. Sustainable Forest Management and Social-Ecological Systems: An Institutional Analysis of Caatinga, Brazil. Forests 2017, 8, 454. [CrossRef]

47. Gari, S.R.; Newton, A.; Icely, J.D.; Delgado-Serrano, M.M. An analysis of the global applicability of Ostrom's design principles to diagnose the functionality of common-pool resource institutions. Sustainability 2017, 9, 1287. [CrossRef]

48. Baggio, J.A.; Barnett, A.J.; Perez-Ibarra, I.; Brady, U.; Ratajczyk, E.; Rollins, N.; Rubiños, C.; Shin, H.C.; Yu, D.J.; Aggarwal, R.; et al. Explaining success and failure in the commons: The configural nature of Ostrom's institutional design principles. Int. J. Commons. 2016, 10, 417-439. Available online: http:/ / www.thecommonsjournal.org/articles/10.18352/ijc.634/ (accessed on 26 January 2021). [CrossRef]

49. Altman, D.G.; Raton, B.; New, L.; Washington, Y. Practical Statistics for Medical Research; CRC Press: Boca Raton, FL, USA, 1990.

50. Landis, J.R.; Koch, G.G. The Measurement of Observer Agreement for Categorical Data. Biometrics 1977, 33, 159. [CrossRef]

51. Kadi, N.; Khelfaoui, M. Population density, a factor in the spread of COVID-19 in Algeria: Statistic study. Bull. Natl. Res. Cent. 2020, 44, 1-7. [CrossRef]

52. Bouba-Olga, O. Does Density Promote the Epidemic? (Episode 26). Poitiers. 2020. Available online: https://blogs.univ-poitiers.fr/obouba-olga/2020/04/29/la-densite-favorise-t-elle-lepidemie-episode-26/ (accessed on 5 October 2020).

53. Tashiro, A.; Shaw, R. COVID-19 pandemic response in Japan: What is behind the initial flattening of the curve? Sustainability 2020, 12, 5250. [CrossRef]

54. Hong, L. Lessons from Abroad: South Korea's Covid-19 Containment Model. Auckland. 2020. Available online: https://apo.org.au/ node/303467 (accessed on 3 September 2020).

55. Tran, B.; Chau, C.; Gregorio, M.D.; Nixon, N. Vietnam: A COVID-19 success story. 2020. Available online: https://asiafoundation. org/2020/05/27/vietnam-a-covid-19-success-story / (accessed on 19 September 2020).

56. Fetzer, T.; Witte, M.; Hensel, L.; Jachimowicz, J.M.; Haushofer, J.; Ivchenko, A.; Caria, S.; Reutskaja, E.; Roth, C.; Fiorin, S.; et al. Measuring Worldwide COVID-19 Attitudes and Beliefs; 2020; Vol. 53. Available online: https:/ / osf.io/zgfjc/download (accessed on 26 January 2021).

57. Huang, J.; Teoh, J.Y.-C.; Wong, S.H.; Wong, M.C. The potential impact of previous exposure to SARS or MERS on control of the COVID-19 pandemic. Eur. J. Epidemiol. 2020, 35, 1099-1103. [CrossRef] [PubMed]

58. World Health Organization. Clinical Management of Human Infection with Pandemic (H1N1) 2009: Revised Guidance. 2009. Available online: http:/ / www.who.int/csr/resources/publications/infection_control/en/index.html (accessed on 28 January 2021). 
59. Bernama. Past Experience With Other Viruses Helped Malaysia Manage Covid-19. 2020. Available online: https://www. nst.com.my/news/nation/2020/07/610391/past-experience-other-viruses-helped-malaysia-manage-covid-19 (accessed on 15 September 2020).

60. Rahman, F. The Malaysian Response to COVID-19: Building Preparedness for 'Surge Capacity', Testing Efficiency, and Containment-From the Desk of the Director-General of Health Malaysia. 2020. Available online: https://kpkesihatan.com/2020 /06/16/the-malaysian-response-to-covid-19-building-preparedness-for-surge-capacity-testing-efficiency-and-containment/ (accessed on 15 September 2020).

61. Nippon.com. Japan's COVID-19 Measures: Controlling the Spread Without Lockdowns. 2020. Available online: https://www. nippon.com/en/in-depth/d00592/ (accessed on 10 September 2020).

62. World Health Organization. Evolution of a Pandemic A(H1N1), 2nd ed.; World Health Organization: Geneva, Switzerland, 2009; ISBN 9789241503051.

63. Human Rights Commission of Malaysia. Issues Facing Migrant and Undocumented Workers Due to COVID-19 and Relevant Recommendations. Available online: https://www.suhakam.org.my/wp-content/uploads/2020/07/SUHAKAM-Matrix-Issuesand-Recommendations-COVID-19-and-Women.pdf (accessed on 27 August 2020).

64. Koh, D. Migrant workers and COVID-19. Occup. Environ. Med. 2020, 77, 634-636. Available online: https://oem.bmj.com/ content/77/9/634 (accessed on 26 September 2020). [CrossRef] [PubMed]

65. Sandanasamy, F.; Paavilainen, M.; Baruah, N. COVID-19: Impact on Migrant Workers and Country Response in Malaysia. 2020. Available online: https://www.ilo.org/asia/publications/issue-briefs/WCMS_741512/lang--en/index.htm (accessed on 13 September 2020).

66. Mazey, S.; Richardson, J. Lesson-Drawing from New Zealand and Covid-19: The Need for Anticipatory Policy Making. Polit. Q. 2020, 91, 561-570. [CrossRef] [PubMed]

67. The Conversation. How Shinzo Abe has Fumbled Japan's Coronavirus Response. 27 April 2020. Available online: https: // theconversation.com/how-shinzo-abe-has-fumbled-japans-coronavirus-response-136860 (accessed on 14 October 2020).

68. Jones, A. Coronavirus: How “Overreaction" made Vietnam a Virus Success. BBC News, 15 May 2020. Available online: https: / / www.bbc.com/news/world-asia-52628283 (accessed on 19 September 2020).

69. World Health Organization WHO. Density of Physicians (Total Number per 1000 Population Latest Available Year); World Health Organization: Geneva, Switzerland, 2018. Available online: http:/ /www.who.int/gho/health_workforce/physicians_density/ en/ (accessed on 25 October 2020).

70. World Health Organization. Hospital Beds (per 10000 Population). 2019. Available online: https://www.who.int/data/gho/ data/indicators/indicator-details/GHO/hospital-beds-(per-10-000-population) (accessed on 26 October 2020).

71. Pisu, M. Tackling the Infrastructure Challenge in Indonesia. Public Adm. Today 2010, 6-11. Available online: https://www.oecdilibrary.org/economics/tackling-the-infrastructure-challenge-in-indonesia_5km5xvc1kk47-en (accessed on 30 September 2020).

72. Setiati, S.; Azwar, M.K. COVID-19 and Indonesia. Acta Med. Indones. 2020, 52, 84-89.

73. United Nations Office for the Coordination of Humanitarian Affairs, The United Nations Resident Coordinator Office. Indonesia Multisectoral Response Plan to COVID-19. 2020. Available online: https://unsdg.un.org/resources/indonesia-multi-sectoralresponse-plan-covid-19 (accessed on 24 September 2020).

74. Falcon, D.J. The Health Care Gap in Rural Malaysia. Vol. 37. 2019. Available online: https://preserve.lehigh.edu/perspectivesv37/6 (accessed on 3 September 2020).

75. Boo, S.-L. How MySejahtera Protects Your Data and Does More Than Contact Tracing. Codeblue. 2020. Available online: https: / / codeblue.galencentre.org/2020/08/12/how-mysejahtera-protects-your-data-and-does-more-than-contact-tracing/ (accessed on 14 September 2020).

76. Nishimura, Y. How Japan Beat Coronavirus without Lockdowns. 2020. Available online: https://www.wsj.com/articles/howjapan-beat-coronavirus-without-lockdowns-11594163172 (accessed on 9 September 2020).

77. Ministry of Health. Background and Overview of Approaches to COVID-19 Pandemic Control in Aotearoa/New Zealand. 2020; pp. 1-21. Available online: https://www.health.govt.nz/system/files/documents/publications/background-overviewapproaches-covid-19-pandemic-contro-aotearoa-new-zealand-30mar20.pdf (accessed on 2 October 2020).

78. Nguyen, T.H.; Vu, D.C. Summary of the COVID-19 outbreak in Vietnam-Lessons and suggestions. Travel Med. Infect. Dis. 2020, 37, 101651. Available online: https:/ / doi.org/10.1016/j.tmaid.2020.101651 (accessed on 19 September 2020). [CrossRef] [PubMed]

79. Ha, B.T.T.; Quang, L.N.; Mirzoev, T.; Tai, N.T.; Thai, P.Q.; Dinh, P.C. Combating the COVID-19 epidemic: Experiences from Vietnam. Int. J. Environ. Res. Public Health 2020, 17, 3125. [CrossRef] [PubMed]

80. Taiwan News. Indonesia Develops 15-Minute Coronavirus Test Kit with 96\% Specificity. Taiwan News. 2020. Available online: https:/ / www.taiwannews.com.tw/en/news/3965142 (accessed on 26 September 2020).

81. Anadolu Agency. Indonesia Produces 50,000 Testing Kits for COVID-19. 2020. Available online: https://www.aa.com.tr/en/asiapacific/indonesia-produces-50-000-testing-kits-for-covid-19/1844999 (accessed on 26 September 2020).

82. The Star. Vietnamese and Japanese Researchers Develop Test Kit for Covid-19. 2020. Available online: https://www.thestar.com.my/ news/regional/2020/05/06/vietnamese-and-japanese-researchers-develop-test-kit-for-covid-19 (accessed on 24 September 2020).

83. Gov Insider. How Singapore is Creating Rapid Covid-19 Test Kits. 2020. Available online: https://govinsider.asia/smart-gov/ astar-how-singapore-is-creating-rapid-covid-19-test-kits / (accessed on 29 September 2020). 
84. The Jakarta Post. From Test Kits to Robots, Indonesia Develops Locally Made Devices to Aid COVID-19 Battle. 2020. Available online: https:/ / www.thejakartapost.com/news/2020/05/06/from-test-kits-to-robots-indonesia-develops-locally-made-devicesto-aid-covid-19-battle.html (accessed on 26 September 2020).

85. South China Morning Post. Coronavirus: Japan's Bid to Ramp up Ventilator Production at Risk of Being Held Up by Red Tape. South China Morning Post, 10 April 2020. Available online: https://www.scmp.com/week-asia/health-environment/article/3079 296/coronavirus-japans-bid-ramp-ventilator-production-risk(accessed on 17 October 2020).

86. The Straits Time. Coronavirus: Singapore Plays Vital Role in Making of Dyson Ventilators Being Rushed Out to Save Lives. 2020. Available online: https:/ /www.straitstimes.com/lifestyle/home-design/coronavirus-singapore-plays-vital-role-in-makingof-dyson-ventilators-being (accessed on 18 October 2020).

87. Reuters. UPDATE 2-Vietnam's Vingroup Says to Produce Ventilators in COVID-19 Fight. 2020. Available online: https: //www.reuters.com/article/health-coronavirus-vietnam-vingroup-idUSL4N2BR2ON (accessed on 18 October 2020).

88. The Edge Market. K-One Ventures Into Ventilator Production Amid COVID-19 Pandemic. 2020. Available online: https://www. theedgemarkets.com/article/kone-ventures-ventilator-production-amid-covid19-pandemic (accessed on 17 October 2020).

89. The Japan Times. Hitachi to Support Ventilator Production Boost. 2020. Available online: https://www.japantimes.co.jp/news/ 2020/05/19/business/corporate-business/hitachi-ventilator-production-boost/ (accessed on 17 October 2020).

90. The Star. Indonesia's Start-Ups Produce Covid-19 Test Kits Locally. The Star, 10 June 2020. Available online: https:/ / www.thestar. com.my / aseanplus / aseanplus-news/2020/06/10/indonesia039s-start-ups-produce-covid-19-test-kits-locally (accessed on 26 September 2020).

91. Voanews.com. Vietnam Poised to Export COVID-19 Test Kits. 2020. Available online: https://www.voanews.com/covid-19 -pandemic/vietnam-poised-export-covid-19-test-kits (accessed on 24 September 2020).

92. Nikkei Asia. As N95 Masks Run Out, Japan Turns to Handful of Domestic Suppliers. 2020. Available online: https:/ /asia.nikkei. com/Spotlight/Coronavirus/As-N95-masks-run-out-Japan-turns-to-handful-of-domestic-suppliers (accessed on 18 October 2020).

93. New Straits Time. Jakarta Steps up Lockdown Rules as Covid-19 Cases Surge. 2020. Available online: https://www.nst.com.my/ world/world/2020/04/583123/jakarta-steps-lockdown-rules-covid-19-cases-surge (accessed on 29 September 2020).

94. Aljazeera. Indonesia: More than 2,200 Died with Coronavirus-Like Symptoms.Indonesia. Al Jazeera. 2020. Available online: https: / / www.aljazeera.com/news/2020/4/28/indonesia-more-than-2200-died-with-coronavirus-like-symptoms (accessed on 26 September 2020).

95. World Bank. Gross Domestic Product 2019, pp. 1-4. 2020. Available online: https://databank.worldbank.org/data/download/ GDP_PPP.pdf (accessed on 18 September 2020).

96. World Bank. Gross National Income per Capita 2019, pp. 1-4. 2020. Available online: http://databank.worldbank.org/data/ download/GNIPC.pdf (accessed on 18 September 2020).

97. The Economist Intelligence Unit. The World Leader in Global Business Intelligence Democracy Index 2019 a Year of Democratic Setbacks and Popular Protest. 2020. Available online: https:/ /www.in.gr/wp-content/uploads/2020/01/Democracy-Index-20 19.pdf (accessed on 8 October 2020).

98. Cerre, M. How Vietnam's Authoritarian Government Succeeded at Containing COVID-19. PBS NewsHour. 2020. Available online: https://www.pbs.org/newshour/show/how-vietnams-authoritarian-government-succeeded-at-containing-covid-19 (accessed on 14 October 2020).

99. Thomson, S.; Ip, E.C. COVID-19 emergency measures and the impending authoritarian pandemic. J. Law. Biosci. 2020, 1-33. Available online: https:/ /academic.oup.com/jlb/advance-article/doi/10.1093/jlb/lsaa064/5912724 (accessed on 28 January 2021). [CrossRef]

100. Bremmer, I. What Japan Can Teach the World About the Pandemic. Time. 2020. Available online: https://time.com/5818228/ japan-coronavirus-response/ (accessed on 9 September 2020).

101. Reuters. "Lockdown", Japan-Style: Pressure to Conform, Not Penalties for Non-Compliance. 2020. Available online: https:/ / www.reuters.com/article/us-health-coronavirus-japan-emergency-ex/lockdown-japan-style-pressure-to-conformnot-penalties-for-non-compliance-idUSKBN21O08J (accessed on 10 September 2020).

102. Assegaf Hamzah \& Partners. Covid-19 Response: Between Lockdown, Quarantine and Massive Social Restriction. Jakarta p. 1-3. 2020. Available online: https:/ / www.ahp.id/client-update-11-april-2020-1?utm_source=Mondaq\&utm_medium=syndication\& utm_campaign=LinkedIn-integration (accessed on 26 September 2020).

103. The Edge. Malaysian Returnees From Abroad Fitted With This Wristband Cannot Take It off During Home Quarantine. 2020. Available online: https://www.theedgemarkets.com/article/malaysian-returnees-abroad-fitted-wristband-cannot-takeit-during-home-quarantine (accessed on 13 September 2020).

104. New Zealand Legislation. COVID-19 Public Health Response Act 2020. 2020. Available online: https://www.legislation.govt.nz/ act/public/2020/0012/latest/LMS344134.html (accessed on 2 October 2020).

105. Channel News Asia. Jail Terms, Fines for Those Who Breach COVID-19 Safe-Distancing Rules, Stay-Home Notice-CNA. 2020. Available online: https:/ / www.channelnewsasia.com/news/singapore/covid-19-stay-home-notice-safe-distancing-jail-fine12581510 (accessed on 17 September 2020).

106. Republic of Korea. Quarantine Act. 2009. Available online: https://elaw.klri.re.kr/eng_mobile/viewer.do?hseq=46420\&type= part\&key=36 (accessed on 8 February 2021). 
107. Dtinews.vn. Hanoi Rolls Out Fines for Violations of COVID-19 Prevention Regulations. 2020. Available online: http:// dtinews.vn/en/news/017004/67249/hanoi-rolls-out-fines-for-violations-of-covid-19-prevention-regulations.html (accessed on 19 September 2020).

108. Astro Awani. No Compromise, Repeat MCO Offenders Will Face 5 Years' Imprisonment-Ismail Sabri. Astro Awani, 11 April 2020. Available online: https://www.astroawani.com/berita-malaysia/no-compromise-repeat-mco-offenders-will-face-5-yearsimprisonment-ismail-sabri-237857 (accessed on 24 September 2020).

109. Nasional Kompas. Penjara dan Denda Rp 1 Miliar Menanti bagi Penyebar Hoaks Virus Corona Halaman All—Kompas.com. 2020. Available online: https:/ / nasional.kompas.com/read/2020/02/04/11383031/penjara-dan-denda-rp-1-miliar-menantibagi-penyebar-hoaks-virus-corona?page=all (accessed on 26 September 2020).

110. Government of Malaysia. Laws of Malaysia Act 588 Communication and Multimedia Act 1998. 1998. Available online: https:/ / www.mcmc.gov.my/skmmgovmy/media/General/pdf/Act588bi_3.pdf (accessed on 8 February 2021).

111. Channel News Asia. Has POFMA been effective? A look at the fake news law, 1 year since it kicked in. 2020. Available online: https:/ / www.channelnewsasia.com/news/singapore/singapore-pofma-fake-news-law-1-year-kicked-in-13163404 (accessed on 8 February 2021).

112. South China Morning Post. April Fool: Coronavirus Hoax K-Pop Star Under Investigation and Could Face Prison Sentence. South China Morning Post, 2 April 2020. Available online: https:/ /www.scmp.com/lifestyle/entertainment/article/3078065/april-foolcoronavirus-hoax-k-pop-star-under-investigation(accessed on 25 October 2020).

113. Nguyen, P.; Pearson, J. Vietnam Introduces “Fake News" Fines for Coronavirus Misinformation. The Star, 15 April 2020. Available online: https: / / www.thestar.com.my/news/world/2020/04/15/vietnam-introduces-039fake-news039-fines-for-coronavirusmisinformation (accessed on 19 September 2020).

114. Channel News Asia. COVID-19: Compulsory to Wear Mask When Leaving the House, Says Lawrence Wong. 2020. Available online: https://www.channelnewsasia.com/news/singapore/covid19-wearing-masks-compulsory-lawrence-wong-12640828 (accessed on 16 October 2020).

115. Republic of Korea. Infectious Disease Control and Prevention Act. 2009. Available online: https://elaw.klri.re.kr/eng_mobile/ viewer.do?hseq=53530\&type $=$ part\&key=36 (accessed on 8 February 2021).

116. Government of Singapore. MOH Pandemic Readiness and Response Plan for Influenza and Other Actue Repiratory Disease (Revised April 2014). 2014. Available online: https://www.moh.gov.sg/docs/librariesprovider5/diseases-updates/interimpandemic-plan-public-ver-_april-2014.pdf (accessed on 17 September 2020).

117. Dighe, A.; Cattarino, L.; Cuomo-Dannenburg, G.; Skarp, J.; Imai, N.; Bhatia, S.; Gaythorpe, K.; Ainslie, K.; Baguelin, M.; Bhatt, S.; et al. Report 25: Response to COVID-19 in South Korea and Implications for Lifting Stringent Interventions. 2020. Available online: https: / / doi.org/10.25561/79388 (accessed on 3 September 2020).

118. Menteri Dalam Negeri Republik Indonesia. Pedoman Tatanan Normal Baru Produktif dan Aman Corona Disease 2019 bagi Aparatur Sipil Negara di Lingkungan Kementerian Dalam Negeri dan Pemerintah Daerah. Indonesia. 2020. Available online: http:/ /itjen.kemenag.go.id/sirandang/peraturan/6156-440-830-keputusan-menteri-dalam-negeri-nomor-440-830-tahun2020-tentang-pedoman-tatanan-normal-. (accessed on 24 September 2020).

119. Government of Singapore. What You Can and Cannot Do during the Circuit Breaker Period. 2020. Available online: https: //www.gov.sg/article/what-you-can-and-cannot-do-during-the-circuit-breaker-period (accessed on 17 September 2020).

120. Cousins, S. New Zealand eliminates COVID-19. Lancet 2020, 395, 1474. Available online: https://www.thelancet.com/journals/ lancet/article/PIIS0140-6736(20)31097-7/fulltext (accessed on 27 September 2020). [CrossRef]

121. Hoang, V.M.; Hoang, H.H.; Khuong, Q.L.; La, N.Q.; Tran, T.T.H. Describing the pattern of the COVID-19 epidemic in Vietnam. Glob Health Action. 2020, 13, 1776526. Available online: https:/ /www.tandfonline.com/doi/full/10.1080/16549716.2020.1776526 (accessed on 19 September 2020). [CrossRef]

122. Apresian, S.R. Responding to the Covid-19 Outbreak in Indonesia: Lessons from European Countries and South Korea. J. Ilm. Hub. Int. 2020, 0, 53-57. [CrossRef]

123. Ryu, S.; Ali, S.T.; Lim, J.; Chun, B.C. Estimation of the Excess COVID-19 Cases in Seoul, South Korea by the Students Arriving from China. 2019, (February 2020). Int. J. Environ. Res. Public Health 2020, 17, 3113. [CrossRef]

124. Aljazeera. 'New normal': Indonesian army set to enforce COVID-19 measures. Coronavirus pandemic News. Al Jazeera. Available online: https://www.aljazeera.com/news/2020/5/26/new-normal-indonesian-army-set-to-enforce-covid-19-measures (accessed on 9 February 2021).

125. Channel News Asia. Malaysian military to help enforce movement curbs to contain COVID-19 - CAN. 2020. Available online: https://www.channelnewsasia.com/news/asia/covid-19-malaysia-deploy-military-movement-control-order-12559958 (accessed on 9 February 2021).

126. Huynh, T.L.D. The COVID-19 Containment in Vietnam: What Are We Doing? J. Glob. Health. 2020, 10, 010338. Available online: http://jogh.org/documents/issue202001/jogh-10-010338.pdf (accessed on 19 September 2020). [CrossRef] [PubMed]

127. Deutsch-Indonesische Industrie-und Handelskammer. COVID-19 Updates in Indonesia-Up to May 2020. 2020. Available online: https:/ /indonesien.ahk.de/en/infocenter/news/news-details/covid-19-updates-in-indonesia-up-to-may-2020 (accessed on 24 September 2020). 
128. The Straits Time. Coronavirus: Indonesia Makes Face Masks Compulsory as Death Toll Nears 200, SE Asia News \& Top Stories-The Straits Times. 2020. Available online: https://www.straitstimes.com/asia/se-asia/coronavirus-indonesia-orderscitizens-to-wear-masks-as-infections-rise (accessed on 16 October 2020).

129. Iwasaki, A.; Grubaugh, N.D. Why does Japan have so few cases of COVID-19? EMBO Mol. Med. 2020, 12, e12481. [CrossRef]

130. The Star. Health DG: Face Masks Not Mandatory, but Encouraged in Public. TheStarTV.com. 2020. Available online: https: //www.thestartv.com/v/health-dg-face-masks-not-mandatory-but-encouraged-in-public (accessed on 4 October 2020).

131. Ministry of Health. COVID-19: Use of Masks and Face Coverings in the Community. Ministry of Health NZ. 2020. Available online: https:/ / www.health.govt.nz/our-work/diseases-and-conditions/covid-19-novel-coronavirus/covid-19-health-advicepublic/covid-19-use-masks-and-face-coverings-community (accessed on 2 October 2020).

132. Voanews.com. Vietnam Imposes Hefty Fines for Going Maskless. 2020. Available online: https://www.voanews.com/sciencehealth/coronavirus-outbreak/vietnam-imposes-hefty-fines-going-maskless (accessed on 19 September 2020).

133. Suraya, I.; Nurmansyah, M.I.; Rachmawati, E.; Al Aufa, B.; Koire, I.I. The impact of large-scale social restrictions on the incidence of covid-19: A case study of four provinces in Indonesia. Kesmas 2020, 15, 49-53. [CrossRef]

134. International Association of Public Transport. Public Transport Authorities and COVID-19: Response from the Front Line. 2020. Available online: https://www.lek.com/sites/default/files/PDFs/COVID19-public-transport-impacts.pdf (accessed on 17 October 2020).

135. New Zealand Government. Cleaning Following a Confirmed or Probable Case of COVID-19. 2020. Available online: https:/ / www.health.govt.nz/our-work/diseases-and-conditions/covid-19-novel-coronavirus/covid-19-information-specificaudiences / covid-19-general-cleaning-and-disinfection-advice/cleaning-following-confirmed-or-probable-case-covid-19 (accessed on 18 October 2020).

136. Abe, S. [COVID-19] Press Conference by the Prime Minister regarding the Novel Coronavirus (Speeches and Statements by the Prime Minister). Prime Minister of Japan and His Cabinet. 2020. Available online: http://japan.kantei.go.jp/98_abe/statement/ 202005/_00003.html (accessed on 9 September 2020).

137. Her, M. Repurposing and reshaping of hospitals during the COVID-19 outbreak in South Korea. One Health $2020,10,100137$. Available online: https:/ / doi.org/10.1016/j.onehlt.2020.100137 (accessed on 16 October 2020). [CrossRef] [PubMed]

138. La, V.-P.; Pham, T.-H.; Ho, M.-T.; Nguyen, M.-H.; Nguyen, K.-L.P.; Vuong, T.-T.; Nguyen, H.-K.T.; Tran, T.; Khuc, Q.; Vuong, Q.-H. Policy Response, Social Media and Science Journalism for the Sustainability of the Public Health System Amid the COVID-19 Outbreak: The Vietnam Lessons. Sustainability 2020, 12, 2931. [CrossRef]

139. Reuters. Vietnam Announces $\$ 1.16 \mathrm{bln}$ Stimulus Package to Help Virus-Hit Businesses-State Media. 2020. Available online: https:/ / www.reuters.com/article/health-coronavirus-vietnam-economy/vietnam-announces-1-16bln-stimulus-packageto-help-virus-hit-businesses-state-media-idINL4N2AW2UX (accessed on 16 October 2020).

140. The Asahi Shimbun. Japan's Low Unemployment Rate Hides Deeper Labor Market Pain. 2020. Available online: http: / / www.asahi.com/ajw/articles/13427311 (accessed on 10 September 2020).

141. NHK World Japan News. Coronavirus Crushing Foreign Workers. NHK WORLD-JAPAN News, 2020. Available online: https: //www3.nhk.or.jp/nhkworld/en/news/backstories/1024/ (accessed on 10 September 2020).

142. Heijmans, P. Coronavirus in Singapore: City-State Scales Up Medical Facilities—Bloomberg. 2020. Available online: https: //www.bloomberg.com/news/articles/2020-04-28/singapore-scaling-up-medical-facilities-as-virus-cases-increase (accessed on 18 September 2020).

143. Thanh, N.; Dinh, T. Hanoi Resuscitates Abandoned Hospital for Covid-19 Quarantine. VnExpress International. 2020. Available online: https: / / e.vnexpress.net/news/news/hanoi-resuscitates-abandoned-hospital-for-covid-19-quarantine-4071654.html (accessed on 16 October 2020). 